\section{The Metabolic Syndrome}

\section{A High-Risk State for Cancer?}

\author{
Stephanie Cowey and Robert W. Hardy \\ From the Department of Pathology, Division of Laboratory \\ Medicine, University of Alabama at Birmingham, \\ Birmingham, Alabama
}

The metabolic syndrome is composed of cardiovascular risk factors including increased body mass index/ waist circumference, blood pressure, plasma glucose, and triglycerides, as well as decreased high-density lipoprotein cholesterol. The essence of the metabolic syndrome lies in the clustering of these risk factors, which are associated with cardiovascular disease. Interestingly, most of the components of the metabolic syndrome have individually been linked in some way to the development of cancer. However, epidemiological studies linking the metabolic syndrome to cancer are scarce. Nevertheless, two such studies indicate that the clustering of metabolic syndrome components significantly increases the risk of colon cancer mortality compared with the individual components. The purpose of this review is to further explore the potential relationship between the metabolic syndrome and cancer risk. Specifically, we examine the hypothesis that individual components of the metabolic syndrome contribute to the development of several processes, including insulin resistance, aromatase activity, adipokine production, angiogenesis, glucose utilization, and oxidative stress/DNA damage, which can work together to increase cancer risk beyond that of the individual components alone. We propose that the metabolic syndrome be considered as a high-risk state for certain types of cancer and that this relationship should be systematically explored across cancer types. (Am J Pathol 2006, 169:1505-1522; DOI: 10.2353/ajpath.2006.051090)

Syndrome can be defined as a group of signs and symptoms that occur together and characterize a particular abnormality. ${ }^{1}$ Insulin resistance, which is a key underlying feature of type 2 diabetes mellitus, has also been shown to be associated with dyslipidemia [hypertriglyc- eridemia and hypohigh-density lipoprotein cholesterol (HDLc)], obesity, and hypertension. ${ }^{2,3}$ These risk factors were combined into the insulin resistance syndrome, or syndrome $X$ as described by Reaven, ${ }^{3}$ and subsequently obesity was included. This syndrome has since become known as the "metabolic syndrome," which is a risk factor for cardiovascular disease (CVD). The metabolic syndrome has been similarly defined by the World Health Organization, the National Cholesterol Education Program's Adult Treatment Panel III (ATP III), and the European Group on Insulin Resistance (Table 1). Although each group appears to agree that dyslipidemia, glucose intolerance, insulin resistance, obesity, and hypertension are components, there are differences in how each defines the metabolic syndrome. Unfortunately, there does not appear to be a clear explanation as to why these differences exist. ${ }^{3}$

According to the ATP III definition of the metabolic syndrome, $\sim 24 \%$ of US adults have the metabolic syndrome (no gender preference). ${ }^{4}$ However, in Mexican Americans, the prevalence is $\sim 32 \%$, and in this group, women are more likely to meet the criteria (1.3-fold versus men). ${ }^{4}$ Likewise, African-American women are more likely to meet the criteria (1.6-fold versus men). ${ }^{4}$ These numbers are likely an underestimate since they are at least 10 years old.

The metabolic syndrome is widely cited in the literature and has its own ICD-9 code (277.7). Nevertheless, it has recently come under fire because of its imprecise definition, the uncertainty of its pathogenesis, and its value as a risk marker for CVD. ${ }^{5}$ Although valid points are raised on both sides of the controversy it should be remembered that similar issues have been raised with other complex metabolic processes such as type 2 diabetes mellitus, in which criticism has lead to new definitions and progress on defining pathogen-

Supported by the National Institutes of Health (grants R21AT01636 to R.W.H. and T32AR047512 to S.C.)

Accepted for publication August 1, 2006

Address reprint requests to Robert W. Hardy, Department of Pathology, University of Alabama at Birmingham, 701 South 19th St., LHRB Room 531, Birmingham, AL 35294-0007. E-mail: hardy@path.uab.edu. 
Table 1. Definitions of the Metabolic Syndrome

\begin{tabular}{|c|c|c|c|}
\hline Risk factors & $\begin{array}{l}\text { National Cholesterol Education } \\
\text { Program's } \\
\text { Adult Treatment Panel III (ATP III) } \\
\text { ( } \geq 3 \text { of } 5 \text { criteria necessary) }\end{array}$ & $\begin{array}{l}\text { World Health Organization } \\
\text { (WHO) } 1999 \text { (impaired } \\
\text { glucose regulation or } \\
\text { hyperinsulinemia and } \geq 2 \text { of } \\
\text { criteria necessary) }\end{array}$ & $\begin{array}{c}\text { European Group on Insulin } \\
\text { Resistance (EGIR) } 2002 \\
\text { (hyperinsulinemia and } \geq 2 \text { of } \\
\text { criteria necessary) }\end{array}$ \\
\hline $\begin{array}{l}\text { Impaired glucose } \\
\text { regulation }\end{array}$ & $\begin{array}{l}110 \text { to } 126 \mathrm{mg} / \mathrm{dl}(6.1 \text { to } 7.0 \mathrm{mmol} / \\
\mathrm{L})\end{array}$ & $\begin{array}{l}\text { Plasma glucose: fasting } \geq 6.1 \\
\mathrm{mmol} / \mathrm{L} \text { or } 2 \text {-hour } \\
\text { postglucose load } \geq 7.8 \\
\mathrm{mmol} / \mathrm{L} \text { or capillary whole } \\
\text { blood glucose: fasting } \\
\geq 5.6 \mathrm{mmol} / \mathrm{L} \text { or } 2 \text {-hour } \\
\text { postglucose load } \geq 7.8 \\
\mathrm{mmol} / \mathrm{L}\end{array}$ & $\begin{array}{l}\text { Fasting plasma } \geq 6.1 \mathrm{mmol} / \mathrm{L} \text { or } \\
\text { capillary whole blood } \geq 5.6 \\
\mathrm{mmol} / \mathrm{L}\end{array}$ \\
\hline Hyperinsulinemia & Not included & $\begin{array}{l}\text { Fasting serum insulin } \geq \text { third } \\
\text { quartile for control group }\end{array}$ & $\begin{array}{l}\text { Fasting serum insulin } \geq \text { third } \\
\text { quartile for nondiabetic } \\
\text { control group }\end{array}$ \\
\hline $\begin{array}{l}\text { Abdominal } \\
\text { obesity }\end{array}$ & $\begin{array}{l}\text { Men: waist circumference } \geq 40 \\
\text { inches }(102 \mathrm{~cm}) \text {; women: waist } \\
\text { circumference } \geq 35 \text { inches ( } 89 \\
\mathrm{~cm} \text { ) }\end{array}$ & $\begin{array}{l}\text { Waist-to-hip ratio }>0.85 \text { or } \\
\qquad \mathrm{BMI}>30 \mathrm{~kg} / \mathrm{m}^{2}\end{array}$ & Waist circumference $>80 \mathrm{~cm}$ \\
\hline Triglycerides & $\geq 150 \mathrm{mg} / \mathrm{dl}(1.7 \mathrm{mmol} / \mathrm{L})$ & $\begin{array}{l}\text { Fasting serum triglyceride } \\
\quad \geq 1.7 \mathrm{mmol} / \mathrm{L}\end{array}$ & $\begin{array}{l}\text { Fasting serum triglyceride }>2.0 \\
\mathrm{mmol} / \mathrm{L} \text { and/or HDLc }<1.0 \\
\mathrm{mmol} / \mathrm{L} \text { and/or treatment for } \\
\text { dyslipidemia }\end{array}$ \\
\hline HDLC & $\begin{array}{l}\text { Men: } \leq 40 \mathrm{mg} / \mathrm{dl}(1.04 \mathrm{mmol} / \mathrm{L}) \\
\text { women: } \leq 50 \mathrm{mg} / \mathrm{dl}(1.3 \mathrm{mmol} / \mathrm{L})\end{array}$ & Not included & Included with triglycerides \\
\hline Hypertension & $\geq 130 / \geq 80 \mathrm{~mm} \mathrm{Hg}$ & $\geq 140 / 90 \mathrm{~mm} \mathrm{Hg}$ & $\begin{array}{l}\text { Systolic blood pressure } \geq 140 \\
\text { mm Hg and/or diastolic } \\
\text { blood pressure } \geq 90 \mathrm{~mm} \mathrm{Hg} \\
\text { and/or treatment for } \\
\text { hypertension }\end{array}$ \\
\hline Microalbuminuria & Not included & $\begin{array}{l}\text { Albumin/creatinine ratio } \geq 30 \\
\mathrm{mg} / \mathrm{g}\end{array}$ & Not included \\
\hline
\end{tabular}

esis. In addition, the central feature of the metabolic syndrome, which is the clustering of cardiovascular risk factors described above, is not in doubt, nor is its association with CVD. ${ }^{6}$

In addition to CVD, individual components of the metabolic syndrome have been linked to the development of cancer. Our purpose here is to highlight the potential increase in cancer risk that is likely associated with the clustering of metabolic syndrome components. We will focus on epidemiological evidence as well as underlying pathophysiologies that link the metabolic syndrome to certain types of cancer.

\section{Epidemiological Evidence Suggesting the Metabolic Syndrome Promotes Cancer}

In the US, one in five adults meets the criteria for the metabolic syndrome and is therefore more susceptible to CVD, type 2 diabetes mellitus, ${ }^{4}$ and possibly cancer. We propose that the metabolic syndrome is composed of a variety of pathologies that can cooperatively contribute to cancer development and progression. The purpose of this section is to review the epidemiological evidence linking components of the metabolic syndrome to cancer; although not inclusive, we have focused on relatively large studies with a multifactorial design. Epidemiology studies are discussed below, beginning with studies examining patients with multiple components of the metabolic syndrome and then examining studies with individual metabolic syndrome risk factors in relation to cancer risk and mortality rates.

\section{Metabolic Syndrome and Colorectal Cancer}

Studies examining cancer incidence in patients diagnosed with the metabolic syndrome are generally lacking; however, two studies indicate that clustering of the components of the metabolic syndrome increases the risk of colorectal cancer mortality compared with the individual components alone. ${ }^{7,8}$ These studies are summarized in Table 2. One study used data from the Chicago Heart Association Detection Project in Industry that, after exclusion of diabetes mellitus, included 20,433 men and 15,149 women, with a median follow-up of 26.2 years. ${ }^{7}$ In this study, the risk factors were plasma glucose, body mass index (BMI), systolic blood pressure, and heart rate, while controlling for several covariates. Men and women combined in the upper quartile of the distribution of the risk factors were categorized as having 0 of 4,1 of 4,2 of 4 , or $\geq 3$ of 4 
Table 2. Referenced Multivariate Epidemiology Studies Examining the Metabolic Syndrome as a Risk for Colorectal Cancer

\begin{tabular}{|c|c|c|}
\hline Study & Trevisan et al, $2001^{8}$ & Colangelo et al, $2002^{7}$ \\
\hline $\begin{array}{l}\text { Results (relative risk ratio } \\
\quad 95 \% \mathrm{Cl} \text { ) }\end{array}$ & $\begin{array}{l}\text { Highest quartile glucose: } M \text { and } F 1.80 \\
\text { (1.05, 3.09), M } 1.83(0.99,3.39), F 1.73 \\
(0.58,5.21) ; \\
\text { IRS (patients with highest quartile of TG } \\
\text { and blood glucose, lowest quartile of } \\
\text { HDLc, and SBP } \geq 140 \text { or DBP } \geq 90 \mathrm{~mm}) \text { : } \\
\text { M and F } 2.99(1.27,7.02), M 2.96(1.05 \\
\text { 8.31), F } 2.71(0.59,12.51)\end{array}$ & $\begin{array}{l}\text { IRS (one of four risk factors-PLG, SBP, BMI, } \\
\text { or heart rate): M and F } 1.05(0.76,1.44), \mathrm{M} \\
1.00(0.66,1.52), \mathrm{F} 1.12(0.69,1.81) ; \\
\text { IRS ( } \geq 3 \text { risk factors) M and F } 1.50(1.03, \\
\text { 2.19), M 1.67 (1.04, 2.70), F } 1.29(0.70,2.37)\end{array}$ \\
\hline Size and type & $\begin{array}{l}\text { Italian men } n=21,311 \text {; women } n=15,991 \text {; } \\
\text { population-based cohort study }\end{array}$ & $\begin{array}{l}\text { American men } n=20,433 \text {, women } n= \\
\text { 15,149; population-based cohort study }\end{array}$ \\
\hline Covariates & Age; smoking; alcohol consumption & $\begin{array}{l}\text { Age; heart rate; smoking; height; SBP; BMI; } \\
\text { postload plasma glucose; education; race; } \\
\text { serum uric acid concentration; alcohol } \\
\text { consumption }\end{array}$ \\
\hline Exclusion & None & Diabetes \\
\hline Nonsignificant studies & HDL; TG; hypertension & $\mathrm{BMI}$ \\
\hline
\end{tabular}

Results refer to cancer mortality. DBP, diabolic blood pressure; IRS, insulin resistance syndrome; PLG, post-load plasma glucose; SBP, systolic blood presure; TG, triglyceride.

risk factors. The graded increases in multivariable adjusted relative risk (RR) of colorectal cancer mortality were $1.67(95 \% \mathrm{Cl}, 1.04$ to 2.7$)$ for men and $1.29(95 \%$ $\mathrm{Cl}, 0.70$ to 2.37 ) for women with $\geq 3$ risk factors, indicating that clustering of components of the metabolic syndrome significantly increases cancer risk in men. In the second study, Trevisan and colleagues ${ }^{8}$ used information from the Risk Factors and Life Expectancy study, which pooled data from nine large epidemiological studies and includes 21,311 men and 15,991 women with a median follow-up of 7 years. In this study serum triglycerides, glucose, HDLc, and blood pressure were analyzed as components of the metabolic syndrome. Trevisan and colleagues ${ }^{8}$ identified patients in the upper quartile of serum glucose and triglycerides and the lower quartile of HDLc or patients on medication for diabetes mellitus or hyperlipidemia as having the insulin resistance syndrome/metabolic syndrome. Men and women combined demonstrated increased risk of death from colorectal cancer from clustering of the components of the metabolic syndrome (men RR, 2.96 and $95 \% \mathrm{Cl}, 1.05$ to 8.31 ; men and women combined $\mathrm{RR}, 2.99$ and $95 \% \mathrm{Cl}, 1.27$ to 7.02 ). Once again colorectal cancer mortality in women was not affected. When analyzing the individual components, only glucose was consistently associated with increased risk of death from colorectal cancer, and only in men and women combined (RR, 1.8; $95 \% \mathrm{Cl}$, 1.05 to 3.09). Relative risk was increased in the cluster analysis compared with glucose alone, suggesting that the effects of the individual components are additive. Furthermore, a recent study done in males also indicates that the metabolic syndrome is associated with increased risk for colorectal adenoma. ${ }^{9}$

In both large studies, ${ }^{6,7}$ the association between the metabolic syndrome and colorectal cancer mortality was stronger for men versus women. However, neither study took into account the menopausal status of women or the use of hormone replacement therapy. It is possible that accounting for these factors may determine that a protective effect of estrogen or progesterone may be masking the true effects of the metabolic syndrome on colorectal cancer development. The Women's Health Initiative estrogen plus progestin trial suggested that hormone replacement therapy with estrogen and progestin reduced invasive colorectal cancer by $44 \%$ compared with placebo $(\mathrm{RR}, 0.56 ; 95 \% \mathrm{Cl}$, 0.38 to 0.81 ); however, when colorectal cancer was present, it was more advanced at the time of diagnosis. ${ }^{10}$ Because observational studies on hormone replacement therapy and colorectal cancer development are conflicting ( 9 of 21 decreased risk, 9 of 21 no effect, 3 of 21 nonsignificant increased risk $^{10}$ ), it is unclear whether female gonadal hormones affect colorectal cancer. These studies indicate that the effects of hormone replacement therapy on colon cancer are complex and may involve progesterone ${ }^{9}$ and/or a reduction or mutation of estrogen receptor $\beta .{ }^{11,12}$ These and other issues related to hormone replacement therapy and colon cancer merit a discussion beyond the scope of this review. Nevertheless, not accounting for hormonal status in women may be a possible explanation for the lack of association between the metabolic syndrome and cancer in women. More research is needed to clarify whether women with the metabolic syndrome will be at increased risk for colon and other cancers, such as breast or endometrial cancer. Interestingly, one small study has recently shown that the metabolic syndrome is a prognostic factor for breast cancer recurrences. ${ }^{13}$ These data, although limited, support the hypothesis that clustering of metabolic risk factors promotes the development and progression of colon cancer in men and indicate that more studies should be conducted.

Many more epidemiological studies have shown an independent correlation between a single risk factor of the metabolic syndrome and cancer. Tables 3 through 8 summarize large epidemiological studies that calculated 
Table 3. Referenced Multivariate Epidemiology Studies That Examine Risk Factors of the Metabolic Syndrome and Cancer Incidence/Mortality for Multiple Kinds of Cancer

\begin{tabular}{|c|c|c|}
\hline Study & Jee et al, $2005^{29}$ & Jee et al, $2005^{29}$ \\
\hline Correlation & $\begin{array}{l}\text { Fasting serum glucose }(>140 \text { versus }<90 \\
\text { mg/dl): cancer mortality }\end{array}$ & $\begin{array}{l}\text { Diabetes (fasting glucose }>125 \mathrm{mg} / \mathrm{dl} \text { or } \\
\text { medication for diabetes): cancer mortality }\end{array}$ \\
\hline $\begin{array}{l}\text { Cancer type } \\
\text { All cancers }\end{array}$ & M $1.22(1.16,1.27) ;$ F $1.15(1.01,1.25)$ & M 1.27 (1.22, 1.33); F $1.31(1.20,1.44)$ \\
\hline Breast & F $0.82(0.61,1.21)$ & F $2.23(1.49,3.33)$ \\
\hline Cervix & F $1.81(1.03,3.15)$ & F $2.50(1.58,3.95)$ \\
\hline Prostate & M $1.14(0.74,1.77)$ & \\
\hline Colorectal & M $1.13(0.98,1.30) ;$ F $1.07(0.84,1.36)$ & F $1.11(0.81,1.51)$ \\
\hline Pancreatic & M $2.09(1.70,2.58)^{\star} ;$ F $1.67(1.09,2.56)^{\star}$ & M $1.71(1.42,2.06) ;$ F $1.71(1.25,2.34)$ \\
\hline Liver & M $1.72\left(1.56,1.89^{*} ;\right.$ F $1.22(0.91,1.63)$ & M $1.59(1.45,1.74) ;$ F $1.28(1.00,1.66)$ \\
\hline Renal & \multicolumn{2}{|l|}{ M $1.26(0.94,1.71)^{\star}$} \\
\hline Esophageal & \multicolumn{2}{|l|}{ M $1.44(1.08,1.93)$} \\
\hline Stomach & \multicolumn{2}{|l|}{ M $1.11(0.97,1.27) ;$ F $1.00(0.74,1.32)$} \\
\hline Size and type & \multicolumn{2}{|c|}{ Korean men $n=829,770$; women $n=468,615$; prospective population-based cohort study } \\
\hline Covariates & \multicolumn{2}{|c|}{ Age; age squared; smoking; alcohol consumption } \\
\hline
\end{tabular}

Table 3-continued

\begin{tabular}{|c|c|c|}
\hline Study & LaVecchia et al, $1994^{31}$ & Calle et al, $2003^{18}$ \\
\hline Correlation & Diabetes: cancer risk & $\begin{array}{l}\left.\text { BMI (>35 versus } 18 \text { to } 24.9 \mathrm{~kg} / \mathrm{m}^{2}\right) \text { : } \\
\text { cancer mortality }\end{array}$ \\
\hline \multicolumn{3}{|l|}{ Cancer type } \\
\hline All cancers & & M $1.52(1.13,2.05)^{\dagger} ;$ F $1.62(1.40,1.87)^{\dagger}$ \\
\hline Breast & F $0.8(0.6,1.0)$ & $F 2.12(1.41,3.19)^{t^{a}}$ \\
\hline Endometrial & F $3.4(2.7,4.3)^{\star}$ & F $6.25(3.75,10.42)^{t^{b}}$ \\
\hline Cervix & & F $3.20(1.77,5.78)^{\dagger}$ \\
\hline Prostate & M $0.7(0.3,1.6)$ & M $1.34(0.98,1.83)^{\dagger}$ \\
\hline Colorectal & $\begin{array}{l}\text { M } 1.2(0.8,1.8) ; F 1.0(0.6,1.5) ; M \text { and } F \\
\quad 0.6(0.4,0.9)^{\star}\end{array}$ & M $1.84(1.39,2.41)^{\dagger} ;$ F $1.46(0.94,2.24)^{\dagger}$ \\
\hline Pancreatic & $\begin{array}{l}\text { M } 2.6(1.8,4.0)^{\star} ; F 1.4(0.8,2.5) ; M \text { and } F \\
\quad 2.1(1.5,2.9)^{\star}\end{array}$ & M $1.49(0.99,2.22)^{\dagger} ;$ F $2.76(1.74,4.36)^{\dagger}$ \\
\hline Liver & $\begin{array}{l}\text { M } 2.8(2.0,3.9)^{\star} ; F 2.5(1.3,4.9)^{\star} ; M \text { and } F \\
\quad 2.8(2.0,3.9)^{\star}\end{array}$ & M $4.52(2.94,6.94)^{\dagger} ;$ F $1.68(0.93,3.05)^{\star}$ \\
\hline Renal & $\begin{array}{l}\text { M } 0.6(0.2,1.5) ; \mathrm{F} 0.5(0.1,2.0) ; M \text { and } F \\
\quad 0.6(0.3,1.2)\end{array}$ & M $1.70(0.99,2.92) ;$ F $4.75(2.50,9.04)^{\dagger}$ \\
\hline Esophageal & $\begin{array}{l}\text { M } 0.9(0.5,1.5) ; \mathrm{F} 0.7(0.2,2.4) ; \mathrm{M} \text { and } \mathrm{F} \\
\quad 0.8(0.5,1.4)\end{array}$ & M $1.63(0.95,2.80)^{\dagger}$ \\
\hline Stomach & $\begin{array}{l}\text { M } 0.6(0.4,1.0)^{*} ; \mathrm{F} 0.7(0.4,1.2) ; \mathrm{M} \text { and } \mathrm{F} \\
\quad 0.6(0.4,0.9)^{\star}\end{array}$ & M $1.94(1.21,3.13)^{\star} ;$ F $1.08(0.61,1.89)$ \\
\hline Non-Hodgkin's Iymphoma & $\begin{array}{l}\text { M } 0.3(0.1,0.8)^{\star} ; \mathrm{F} 0.6(0.2,1.8) ; \mathrm{M} \text { and F } \\
\quad 0.3(0.1,0.8)^{*}\end{array}$ & M $1.49(0.93,2.39)^{\dagger} ;$ F $1.95(1.39,2.72)^{\dagger}$ \\
\hline Size and type & $\begin{array}{l}\text { Italian men and women; cases } n=9991 \\
\text { controls } n=7834 ; \text { population-based } \\
\text { case control study }\end{array}$ & $\begin{array}{l}\text { American men } n=404,576 \text {; women } n= \\
\text { 495,477; prospective population-based } \\
\text { cohort study }\end{array}$ \\
\hline Covariates & Age & $\begin{array}{l}\text { Age; education; smoking; number of } \\
\text { cigarettes; physical activity; marital status; } \\
\text { race; aspirin use; estrogen-replacement } \\
\text { therapy (women only); fat, vegetable, and } \\
\text { alcohol consumption }\end{array}$ \\
\hline Exclusion & & $\begin{array}{l}\text { Patients who lost }>10 \text { pounds } 1 \text { year prior to } \\
\text { study; BMl }<18.5 \mathrm{~kg} / \mathrm{m}^{2} \text {; cancer at } \\
\text { baseline }\end{array}$ \\
\hline
\end{tabular}

${ }^{\star} P<0.05$.

${ }^{\dagger} P<0.001$

apremenopausal and perimenopausal women excluded

bWomen with hysterectomy excluded. 


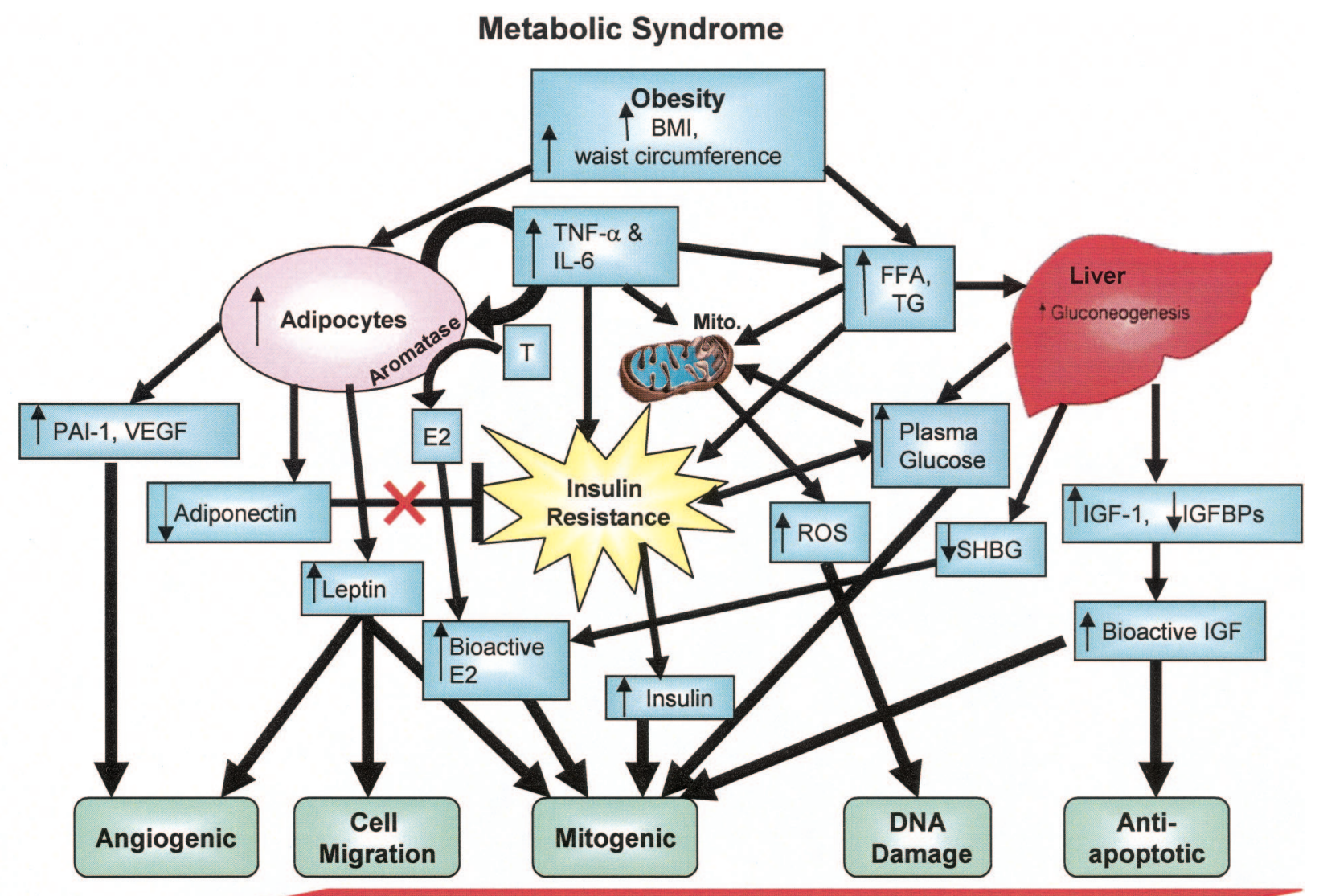

\section{Promotion of Cancer Development /Growth}

Figure 1. Diagram of factors linking the MS with cancer development. Plasma glucose, BMI/waist circumference, and triglycerides/FFA affect different complementary processes that can work together to promote cancer development/growth. Additional characteristics of the MS, such as increased HDL and hypertension, are also correlated with cancer growth, but a direct mechanism for these associations has not been confirmed. Abbreviations: $\mathrm{E}$, estrone; $\mathrm{E}_{2}$ estradiol; A, androgens; mito, mitochondria; ROS, reactive oxygen species; SHBG, sex hormone-binding globulin; FFA, free or nonesterified fatty acids; TG, triglycerides; IGFBPs, insulin-like growth factor-binding proteins.

relative risk $(\mathrm{RR})$ ratios for cancer risk/mortality. Note that significant $P$ values are indicated when stated in the study. The tables are not intended to be comprehensive but are representative.

\section{Obesity}

Obesity, whether defined by waist/hip ratio (WHR) or BMI $\left(\mathrm{kg} / \mathrm{m}^{2}\right)$, has clearly been linked to cancer. BMI is commonly used as a measure of obesity because it is easily calculated from a questionnaire assessing the weight and height of the patient. Epidemiological studies indicate that increased waist circumference and/or BMI is positively correlated with the development of cancers of the colon, breast (postmenopausal), endometrium, esophagus, liver, gallbladder, gastric cardia, and kidney. ${ }^{14-17}$ Furthermore, a large prospective study by Calle and colleagues $^{18}$ demonstrated that increasing BMI is associated with increased mortality from many types of cancer (Table 3). The authors suggest that increased BMI (>25 kg/m²) contributes to 90,000 cancer-related deaths per year in the US.

WHR is used to assess central obesity, or the presence of excess fat in the abdomen. Central adiposity may be a better anthropometric indicator of insulin resistance, attributable at least in part to increased lypolysis from abdominal fat cells. ${ }^{14}$ In addition, abdominal obesity is correlated with decreased concentrations of sex hormone-binding globulin (SHBG) and the conversion of androgens to estrogen, a mitogenic growth factor for hormone-dependent cancers (see Insulin Resistance/Hyperinsulinemia). ${ }^{19,20}$ WHR is positively correlated with colorectal, breast (postmenopausal women), and endometrial cancers in several studies in which BMI was not significantly associated with cancer risk. ${ }^{21-23}$

Weight gain or loss may also be an important factor in cancer risk, depending on its magnitude, the fat distribution, and stage of life of the patient. Numerous studies have demonstrated that adult weight gain (after the age of 18; measured as a change in BMI or $\mathrm{kg}$ ) is significantly correlated with an increased risk of postmenopausal breast cancer in the absence of hormone replacement therapy (Table 6). ${ }^{19,20}$ Studies reporting changes in WHR have cited increases in abdominal fat as a potential culprit. ${ }^{19}$ Likewise, $\mathrm{Xu}$ and colleagues ${ }^{24}$ demonstrated that weight gain (particularly in perimenopausal women age 40 to 50 years) significantly increases the risk of endometrial cancer, irrespective 
Table 4. Referenced Multivariate Epidemiology Studies Examining Metabolic Syndrome Risk Factors and Cancer Incidence/Mortality for Colorectal Cancer

\begin{tabular}{|c|c|c|}
\hline Study & Nilsen and Vatten, $2001^{26}$ & Hou et al, $2006^{16}$ \\
\hline $\begin{array}{l}\text { Results (relative risk ratio } \\
95 \% \mathrm{Cl} \text { ) }\end{array}$ & $\begin{array}{l}\text { Physical activity frequency: M } 0.69(0.50, \\
0.95)^{\star} \text { F } 1.12(0.83,1.52) ; \\
\text { Physical activity index: M } 0.54(0.37,0.79)^{*} \\
\text { F } 0.81(0.54,1.23) ; \\
\text { Physical activity (metastatic cancer risk) M } \\
0.33(0.16,0.67)^{\star}, \mathrm{F} 0.77(0.43,1.38) ; \\
\text { History of DM: M } 0.66(0.35,1.24) \mathrm{F} 1.55 \\
(1.04,2.31) ; \\
\text { Blood glucose }(\geq 8.0 \mathrm{mmol} / \mathrm{L} \text { versus }<8.0 \\
\text { mmol/L): M } 0.90(0.58,1.40) \text { F } 1.98(1.31 \\
2.98)\end{array}$ & $\begin{array}{l}\text { BMI Q5 }\left(>22.8 \mathrm{~kg} / \mathrm{m}^{2}\right) \text { versus Q1 }(<19.2 \mathrm{k} \\
\left.\text { m }^{2}\right): \text { M } 1.7(1.1,2.4)^{\star} \\
\text { BMI Q5 }\left(>23 \mathrm{~kg} / \mathrm{m}^{2}\right) \text { versus Q1 } \\
\left(<19.0 \mathrm{~kg} / \mathrm{m}^{2}\right): \\
\text { Pre BMI Q5 }\left(>23.6 \mathrm{~kg} / \mathrm{m}^{2}\right) \text { versus Q1 } \\
\left(<19.0 \mathrm{~kg} / \mathrm{m}^{2}\right): \mathrm{F} 2.9(1.7,8.6)^{\star} ; \\
\text { Post BMI Q5 }\left(>23.6 \mathrm{~kg} / \mathrm{m}^{2}\right) \text { versus Q1 } \\
\left(<19.0 \mathrm{~kg} / \mathrm{m}^{2}\right): \mathrm{F} 0.6(0.3,0.9)^{*} ; \\
\text { (Pre + Post) F } 1.4(1.0,2.1)\end{array}$ \\
\hline Size and type & $\begin{array}{l}\text { Norwegian men } n=36,975 \text {; Norwegian } \\
\text { women } n=38,244 \text {; population-based } \\
\text { cohort study }\end{array}$ & $\begin{array}{l}\text { Chinese men } n=462 \text { cases, } n=851 \\
\text { controls; Chinese women } n=469 \text { cases } \\
n=701 \text { controls; population-based case } \\
\text { control study }\end{array}$ \\
\hline Covariates & $\begin{array}{l}\text { BMI; physical activity; diabetes; blood } \\
\text { glucose; marital status; education }\end{array}$ & $\begin{array}{l}\text { Age; monthly income; marital status; total } \\
\text { energy intake; intake of red meat, } \\
\text { carotene, and fiber; parity and years of } \\
\text { menstruation (women only) }\end{array}$ \\
\hline Inclusion & No history of cancer at baseline & $\begin{array}{l}\text { Cases: histologically confirmed colorectal } \\
\text { carcinoma in situ; controls: no history of } \\
\text { colorectal carcinoma in situ or } \\
\text { inflammatory bowel disease }\end{array}$ \\
\hline
\end{tabular}

Exclusion

Nonsignificant studies $\quad \mathrm{BMI}$ and the following variables for metastatic cancer: frequency of physical activity, physical activity index, history of diabetes, and blood glucose

Results refer to cancer risk unless otherwise stated. Pre, premenopausal; Post, postmenopausal; Peri, perimenopausal.

${ }^{\star} P<0.01$.

(table continues)

of BMI (Table 8). A 20-kg weight gain since the age of 20 years was associated with a threefold increase in endometrial cancer risk in both pre- and postmenopausal women, whereas a loss of $\geq 2.5 \mathrm{~kg}$ since the age of 20 significantly reduced the risk of cancer in premenopausal women (RR, $0.4 ; 95 \% \mathrm{Cl}, 0.2$ to 1.0 ) but not significantly in postmenopausal women (RR, $0.7 ; 95 \% \mathrm{Cl}, 0.4$ to 1.5$)$. Similar studies have correlated increased risk of colorectal cancer with weight gain, but it was not independent of BMI. ${ }^{25}$ It should be noted that most studies rely on surveys or anthropometric measures (usually BMI) to compare weight change in their study population; thus, weight gain/loss was not determined as fat or muscle.
In contrast to weight gain, exercise can improve insulin-stimulated glucose disposal and thereby reduce colorectal cancer risk and metastasis in men. ${ }^{26} \mathrm{~A}$ single session of physical activity can significantly lower plasma glucose levels in obese rodent models and type 2 diabetic patients. ${ }^{27}$ A large meta-analysis examined the association of physical activity with cancer risk; 35 of 48 colon/colorectal cancer studies and 26 of 41 breast cancer studies reported a dose-responsive decrease in colon and (pre-, peri-, and postmenopausal) breast cancer risk with exercise. ${ }^{28}$ More studies are required to determine whether exercise consistently reduces cancer risk in a dose-dependent manner for other specific sites. 
Table 4. Continued

\begin{tabular}{|c|c|}
\hline Bird et al, $1998^{25}$ & Schoen et al, $1999^{22}$ \\
\hline 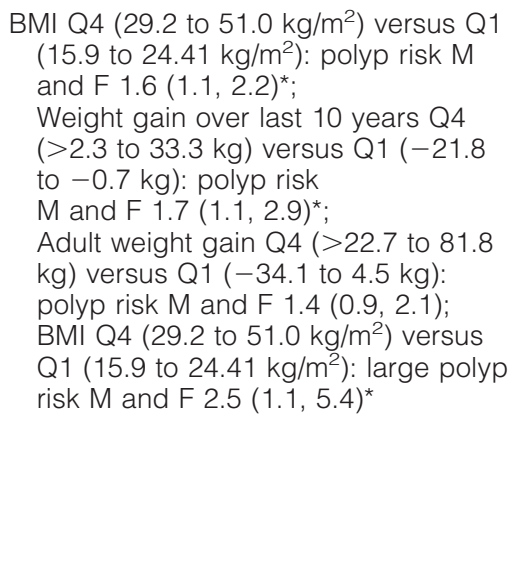 & 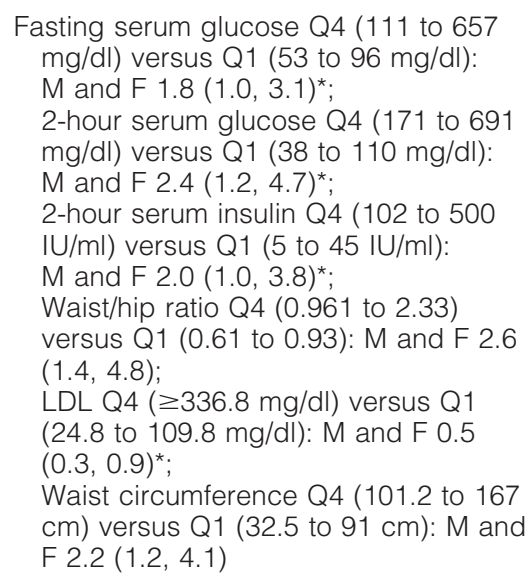 \\
\hline $\begin{array}{l}\text { American men and women, cases }= \\
483 \text {, controls } n=483 \text {; case control } \\
\text { study }\end{array}$ & $\begin{array}{l}\text { American men and women, } n=5849 \\
\text { prospective population-based cohort } \\
\text { study }\end{array}$ \\
\hline $\begin{array}{l}\text { Sex; age; date of sigmoidoscopy; } \\
\text { smoking; race; regular use of NSAID; } \\
\text { vigorous leisure time; exercise }>3 \\
\text { times/week; caloric intake; dietary } \\
\text { fiber }\end{array}$ & Age; sex; physical activity \\
\hline \multicolumn{2}{|l|}{$\begin{array}{l}50 \text { to } 75 \text { years old; cases: diagnosed } \\
\text { for the first time with histologically } \\
\text { confirmed adenomatous polyps; } \\
\text { controls: no adenomas or polyps }\end{array}$} \\
\hline \multicolumn{2}{|l|}{$\begin{array}{l}\text { Invasive cancer; inflammatory bowel } \\
\text { disease; familial polyposis; previous } \\
\text { bowel surgery }\end{array}$} \\
\hline $\begin{array}{l}\text { BMI } 5 \text { years before; BMI } 10 \text { years } \\
\text { before; BMI at age } 18 \text { years; height; } \\
\text { net weight gain over the last } 5 \text { years; } \\
\text { number of large weight changes } \\
\text { ( } \geq 4.5 \mathrm{~kg} \text { ); number of rapid large } \\
\text { weight changes ( } \geq 4.5 \mathrm{~kg} \text { in } \leq 5 \\
\text { years) }\end{array}$ & $\begin{array}{l}\text { BMI; HDL; TG; glucose intolerance; } \\
\text { diabetes; fasting insulin }\end{array}$ \\
\hline
\end{tabular}

\section{Impaired Glucose Regulation and Hyperinsulinemia}

A recent study by Jee and colleagues ${ }^{29}$ examining hyperglycemia in Korea found that elevated fasting glucose levels were associated with increased risk of pancreatic, liver, and renal cancers and contributed to mortality from numerous other types of cancer (see Table 3 for relative risks). Likewise, other groups have found that elevated serum glucose levels $(>6.1 \mathrm{mmol} / \mathrm{L}$ or $\geq 111 \mathrm{mg} / \mathrm{dl}$ ) are significantly correlated with increased risk of endometrial ${ }^{15}$ and colorectal ${ }^{22}$ cancers in their cohort studies. However, patients with diabetes mellitus were not excluded from these studies or controlled for as a covariate (Table 3). Nilsen and Vatten ${ }^{26}$ controlled for diabetes mellitus in their large cohort study ( $n=36,975$; Table 4 ) and still found a significant correlation of blood glucose to colorectal cancer risk in women but not men (RR, 1.98; $95 \% \mathrm{Cl}, 1.31$ to 2.98).

More commonly, cancer epidemiological studies have examined increased blood glucose concentrations with cancer risk in the context of the presence or absence of type 2 diabetes mellitus. In type 2 diabetes mellitus, long-term insulin resistance leads to diminished insulin production from the pancreas, resulting in hypoinsulinemia and elevated blood glucose concentrations. ${ }^{30}$ Diabetes mellitus is correlated with liver, endometrial, pancreatic, cervical, and breast incidence or mortality (Table 3). ${ }^{26,29,31}$ In addition, increased fasting insulin levels in nondiabetic patients are significantly and independently associated with development of colorectal, breast, endometrial, and prostate cancers. ${ }^{32-35}$ These studies indicate that hyperglycemia, diabetes mellitus, and hyperinsulinemia 
Table 5. Referenced Multivariate Epidemiology Studies Examining Metabolic Syndrome Risk Factors and Cancer Incidence/Mortality for Breast Cancer

\begin{tabular}{|c|c|c|}
\hline Study & Goodwin et al, $2002^{34}$ & Kaaks et al, $1998^{23}$ \\
\hline $\begin{array}{l}\text { Results (relative } \\
\quad \text { risk ratio } 95 \% \mathrm{Cl} \text { ) }\end{array}$ & $\begin{array}{l}\text { Insulin Q4 }(51.9 \text { to } 339.8 \mathrm{pmol} / \mathrm{L}) \text { versus Q1 } \\
(8.1 \text { to } 27.0 \mathrm{pmol} / \mathrm{L}): \text { cancer mortality } 3.1 \\
(1.7,5.7) ; \\
\text { BMI Q4 }\left(27.8 \text { to } 54.8 \mathrm{~kg} / \mathrm{m}^{2}\right) \\
\text { versus Q1 }\left(16.3 \text { to } 21.9 \mathrm{~kg} / \mathrm{m}^{2}\right) \text { : cancer } \\
\text { mortality } 1.78(1.25,2.53)\end{array}$ & $\begin{array}{l}\text { Pre waist/hip ratio }(>0.80 \text { versus } \leq 0.73): 0.96 \\
\quad(0.60,1.54) \\
\text { Post waist/hip ratio }(>0.80 \text { versus } \leq 0.73) \text { : } \\
2.63(1.09,6.35)^{\ddagger}\end{array}$ \\
\hline Size and type & $\begin{array}{l}\text { Canadian women } n=512 \text {; prospective cohort } \\
\text { study }\end{array}$ & $\begin{array}{l}\text { Dutch pre women } n=5891 \text {; post women } \\
\quad n=3521 ; \text { population-based cohort study }\end{array}$ \\
\hline Covariates & $\begin{array}{l}\text { Age at diagnosis; tumor stage; tumor grade; } \\
\text { hormone receptor status; adjuvant } \\
\text { chemotherapy; adjuvant tamoxifen }\end{array}$ & $\begin{array}{l}\text { Age; age at menarche; age at first childbirth; } \\
\text { number of liveborn children; menopausal } \\
\text { status; age at menopause }\end{array}$ \\
\hline Inclusion & $\begin{array}{l}\text { Age }<75 \text { years; lumpectomy for breast } \\
\text { cancer; axillary node dissection }\end{array}$ & \\
\hline Exclusion & $\begin{array}{l}\text { Prior malignancy; diabetes } 1 \text { or } 2 \text {; } \\
\text { medications influencing variable }\end{array}$ & \\
\hline $\begin{array}{l}\text { Nonsignificant } \\
\text { studies }\end{array}$ & Estradiol; IGF-1; IGF-2 & $\begin{array}{l}\text { BMl; waist circumference; height; weight; hip } \\
\text { circumference }\end{array}$ \\
\hline
\end{tabular}

(table continues)

can be risk factors for cancer development and underscore the importance of insulin and glucose regulation for suppressing aberrant cell proliferation.

\section{Dyslipidemia}

Suppressed HDLc and elevated triglycerides in patients are also risk factors for colon, breast, and prostate cancers. $^{33,35,36,37}$ One large, long-term, prospective study controlling for such factors as BMI, age, height, blood pressure, and total serum cholesterol demonstrated that postmenopausal women with increased HDLc had a significantly reduced risk of developing breast cancer (RR, $0.75 ; 95 \% \mathrm{Cl}, 0.58$ to 0.97 ; Table 5). ${ }^{36}$ When patients were stratified by BMI, overweight or obese $(\geq 25 \mathrm{BMI})$ postmenopausal patients in the highest quartile of HDLC levels (>1.64 mmol/L) had a dramatically reduced risk of developing breast cancer (RR, $0.43 ; 95 \% \mathrm{Cl}, 0.28$ to 0.67) compared with obese patients in the lowest quartile of HDLc. ${ }^{36}$ Thus, postmenopausal women with low plasma HDLc (particularly those with a BMI $\geq 25 \mathrm{~kg} / \mathrm{m}^{2}$ ) are more susceptible to developing breast cancer than women with normal to high plasma HDLc; however, fast- ing insulin levels/diabetes mellitus were not considered as covariates, despite the strong relationship between insulin resistance and a BMI $>25 \mathrm{~kg} / \mathrm{m}^{2}$, so decreased HDLc may not be an independent risk factor. Likewise, a recent case control study excluding patients with diabetes mellitus reported lower concentrations of HDLc in breast cancer patients $(40.75 \pm 5.44 \mathrm{mg} / \mathrm{dl})$ versus healthy patients $(56.77 \pm 5.63 \mathrm{mg} / \mathrm{dl}, P<0.05){ }^{37}$

Hypertriglyceridemia may be a prognostic indicator for prostate cancer according to one recent Swiss case control study that controlled for age, BMI, diabetes mellitus, and statin medication. ${ }^{38}$ Furthermore, prostate cancer progression to grade 3 is accompanied with a significant increase in serum triglycerides (grade 3, $1.50 \mathrm{mmol} / \mathrm{L}$ versus grade $1,1.21 \mathrm{mmol} / \mathrm{L}$; $P=0.019) .{ }^{35}$ In contrast, several large American cohort studies have demonstrated that serum triglycerides do not correlate with colorectal cancer. ${ }^{8,22,39}$ The effects of serum triglycerides on breast cancer incidence is controversial, since several small studies indicated that triglycerides are a significant risk factor for breast cancer ${ }^{37,40}$; however, large $(n>300$ cases $)$ multivariate studies were unable to confirm these find- 
Table 5. Continued

\begin{tabular}{|c|c|c|}
\hline Furberg et al, $2004^{36}$ & Lahmann et al, $2004^{17}$ & Tehard and Clavel-Chapelon, $2006^{55}$ \\
\hline $\begin{array}{l}\text { Post HDLc Q4 }(\geq 1.64 \mathrm{mmol} / \mathrm{L}) \\
\text { versus Q1 }(<1.20 \mathrm{mmol} / \mathrm{L}): 0.75 \\
(0.58,0.97)^{\star} \\
\text { Post HDLc Q4 }(\geq 1.64 \mathrm{mmol} / \mathrm{L}) \\
\text { versus Q1 }(<1.20 \mathrm{mmol} / \mathrm{L}) \\
\text { BMI } \geq 25 \mathrm{~kg} / \mathrm{m}^{2}: 0.43(0.28,0.67)^{\dagger}\end{array}$ & $\begin{array}{l}\text { Post (no HRT) BMI }(\geq 30.0 \text { versus } \\
\left.<25 \mathrm{~kg} / \mathrm{m}^{2}\right): 1.31(1.08,1.59) ; \\
\text { Pre hip circumference }(\geq 108.0 \\
\text { versus }<94.0 \mathrm{~cm}): 1.70(1.05, \\
2.77)^{\star} ; \\
\text { Post hip circumference }(\geq 108.0 \\
\text { versus }<94.0 \mathrm{~cm}): 1.56(1.12, \\
2.17) ; \\
\text { Post weight }(\geq 75 \text { versus }>56.8 \\
\text { kg): cancer risk } 1.65(1.32,2.08)\end{array}$ & $\begin{array}{l}\text { Pre BMI }\left(\mathrm{Q} 4 \geq 24.4 \mathrm{~kg} / \mathrm{m}^{2} \text { versus }\right. \\
\left.\text { Q1 }<18.5 \mathrm{~kg} / \mathrm{m}^{2}\right): 0.61(0.42, \\
\text { 0.89)*; } \\
\text { Post BMI }\left(\mathrm{Q} 4 \geq 25.1 \mathrm{~kg} / \mathrm{m}^{2} \text { versus }\right. \\
\left.\text { Q1 }<20.0 \mathrm{~kg} / \mathrm{m}^{2}\right): 1.21(0.96,1.52) ; \\
\text { Pre weight Q4 }(>65 \mathrm{~kg}) \text { versus Q1 } \\
(<54 \mathrm{~kg}): 0.57(0.42,0.98)^{*}\end{array}$ \\
\hline $\begin{array}{l}\text { Post Norwegian women } n=13,519 ; \\
\text { pre women } n=25,304 ; \\
\text { prospective population-based } \\
\text { cohort study }\end{array}$ & $\begin{array}{l}\text { Post women } n=103,344 \text {; pre } \\
\text { women } n=73,542 \text {; prospective } \\
\text { population-based cohort study }\end{array}$ & $\begin{array}{l}\text { Post French women } n=42,357 \text {; pre } \\
\text { women } n=20,839 ; \text { prospective } \\
\text { cohort study }\end{array}$ \\
\hline $\begin{array}{l}\text { Age; height; BMI; serum cholesterol; } \\
\text { recreational activity; occupational } \\
\text { activity; parity; menopausal } \\
\text { status; country of residence }\end{array}$ & $\begin{array}{l}\text { Study center; age; education; } \\
\text { smoking; alcohol consumption; } \\
\text { parity; age at first pregnancy; age } \\
\text { at menarche; current pill use; BMI }\end{array}$ & $\begin{array}{l}\text { Family history of breast cancer in } \\
\text { first degree relatives; age at } \\
\text { menarche; age at first birth; } \\
\text { benign breast disease; alcohol } \\
\text { consumption; education; marital } \\
\text { status; physical activity (BMI not } \\
\text { controlled for pre weight) }\end{array}$ \\
\hline \multicolumn{3}{|l|}{$\begin{array}{l}\text { Cancer-free and alive } 1 \text { year after } \\
\text { the study started }\end{array}$} \\
\hline $\begin{array}{l}\text { Pregnancy during the survey; } \\
\text { primary amenorrhea }\end{array}$ & $\begin{array}{l}\text { Surgical menopause or uncertain of } \\
\text { menopause state }\end{array}$ & $\begin{array}{l}\text { Undefined menopausal status; } \\
\text { women who never menstruated; } \\
\text { cancer other than basal cell } \\
\text { carcinoma }\end{array}$ \\
\hline HDLc with $\mathrm{BMI}$ in pre women & $\begin{array}{l}\text { BMI (pre); waist circumference; } \\
\text { waist/hip ratio; height; weight }\end{array}$ & $\begin{array}{l}\text { Waist/hip ratio; hip circumference; } \\
\text { height; breast circumference; } \\
\text { waist circumference; thorax } \\
\text { circumference }\end{array}$ \\
\hline
\end{tabular}

ings. ${ }^{41,42}$ Because triglyceride and HDLc levels are closely linked, studies controlling for these factors are necessary to establish that the effects are independent of one another. Nevertheless, there is good epidemiological evidence to support the association of reduced HDLc with certain types of cancer development, but triglycerides may only be weakly related to cancer incidence. Further studies are needed to clarify the potential role of hypertriglyceridemia in cancer.

\section{Hypertension}

Most studies that examined the correlation between cancer development and hypertension have failed to demonstrate a statistically significant association when BMI was controlled for. ${ }^{8,35,43}$ However, Grossman and colleagues ${ }^{43}$ performed a meta-analysis of the association between hypertension and kidney, breast, and overall cancer mortality using 28 longitudinal or case-control studies (12 of which controlled for BMI and three of which controlled for diabetes mellitus). Four of the 12 studies controlling for BMI found a positive correlation with hypertension, although only two of the studies had confidence intervals that were $>1.00$. Of the three studies controlling for diabetes mellitus, two studies showed a positive correlation, but only one was significant $(\mathrm{Cl}$, >1.00). Nevertheless, the meta-analysis revealed that hypertension (particularly systolic blood pressure) was associated with general cancer mortality (RR, 1.23; 95\% $\mathrm{Cl}, 1.11$ to 1.36 ) and was specifically correlated with renal cancer mortality (adjusted RR for smoking and age $1.75 ; 95 \% \mathrm{Cl}, 1.61$ to 1.90$)$. The authors concluded that hypertension is associated with a $23 \%$ increased risk of overall cancer mortality. Likewise, one large multivariate cohort study ( $n=24,460$; Table 7 ) found a significant risk of endometrial cancer associated with hypertensive women. ${ }^{15}$ The mechanism for this association is unknown and requires further prospective studies that account for BMI, waist circumference, HDLc, and insulin resistance, which have been independently associated with hypertension. ${ }^{44,45}$ At the present time, there is not sufficient evidence to indicate that hypertension per se increases cancer risk.

\section{Summary of Epidemiological Data}

The epidemiological data presented support a relationship between obesity (measured by BMI, waist circumference, or WHR), as well as hyperinsulinemia (measured by fasting insulin levels, insulin after glucose challenge, or diabetes mellitus), and the development of colon and certain other types of cancer. Although some evidence substantiates that hyperglycemia may 
Table 6. Referenced Multivariate Epidemiology Study Examining Metabolic Syndrome Risk Factors and Cancer Incidence/Mortality for Breast Cancer

\begin{tabular}{|c|c|}
\hline Study & Morimoto et al, $2002^{20}$ \\
\hline Results (relative risk ratio 95\% Cl) & $\begin{array}{l}\text { BMI at baseline }\left(>31.1 \text { versus } \leq 22.6 \mathrm{~kg} / \mathrm{m}^{2}\right): 2.52(1.62,3.93)^{\dagger} \\
\text { BMl } \Delta \text { base, age } 18 \text { years }(>9.7 \text { versus } \leq 0): 1.92(1.07,3.43)^{\dagger} \\
\text { BMI } \Delta \text { base, } 50 \text { years }\left(>4 \text { versus } \leq 0 \mathrm{~kg} / \mathrm{m}^{2}\right): 1.45(0.98,2.15)^{\star} \\
\text { BMl at age } 50 \text { years }\left(>31.1 \text { versus } \leq 22.6 \mathrm{~kg} / \mathrm{m}^{2}\right): 2.07(1.32,2.35)^{\star} ; \\
\text { Max BMl }\left(>31.1 \text { versus } 22.6 \mathrm{~kg} / \mathrm{m}^{2}\right): 2.24(1.31,3.84)^{\dagger} ; \\
\text { Waist circ }(>95 \text { versus } \leq 73 \mathrm{~cm}): 1.99(1.31,3.02)^{*}\end{array}$ \\
\hline Size and type & $\begin{array}{l}\text { American postmenopausal women } n=85,917 \text { (never used HRT); population- } \\
\text { based cohort study }\end{array}$ \\
\hline Covariates & $\begin{array}{l}\text { Age; education; age at menopause; age at first birth; first degree of relative family } \\
\text { history; smoking; age at menarche; race; alcohol consumption; recreation } \\
\text { physical activity; dietary energy (kcal) }\end{array}$ \\
\hline Inclusion & $\begin{array}{l}\text { Postmenopausal; age } 50 \text { to } 79 \text {; only invasive carcinomas considered as breast } \\
\text { cancer cases; all data shown are from patients with no HRT }\end{array}$ \\
\hline Exclusion & $\begin{array}{l}\text { History of breast cancer at enrollment; bilateral mastectomy; age }<55 \text { with } \\
\text { undetermined menopause date; extreme anthropometric measurements }\end{array}$ \\
\hline Nonsignificant studies & Waist/hip ratio; height \\
\hline
\end{tabular}

Results refer to cancer risk. Base, baseline; circ, circumference; HRT, hormone replacement therapy; Max, maximum

${ }^{\star} P<0.05$.

${ }^{\dagger} P<0.001$

be a risk factor for colorectal and endometrial cancers, more studies are needed that control for both BMI and diabetes mellitus/hyperinsulinemia. The effects of decreased HDLc or increased triglycerides on cancer risk are controversial, because there are studies to support and refute this finding; HDLc and triglycerides may be important variables when considered with other risk factors, but more multivariate studies are needed to confirm the role of these risk factors in cancer development. Finally, more studies evaluating the relationship between hypertension and cancer risk are needed to determine whether this is an independent risk factor for cancer; at present, the data are relatively weak because of the absence of controlling for confounding factors. In summary, many studies have examined the relationship between the independent risk factors of metabolic syndrome and cancer, but few studies have investigated cancer incidence in patients with the metabolic syndrome. Two studies indicated that patients with $\geq 3$ components of the metabolic syndrome are more at risk of dying from colorectal cancer, than patients with one or two of the independent risk factors. ${ }^{7,8}$ These findings suggest that the metabolic syndrome may be a predictor of colorectal cancer-related mortality; this association should be considered further in relation to other types of cancer in future studies. A better understanding of the underlying pathophysiology for the association between the metabolic syndrome and cancer may provide new insight into the potential additive or synergistic effects of the components of the metabolic syndrome, the development of cancer treatment modalities and may strengthen the clinical relevance of treating patients who meet the criteria for this insidious syndrome.

\section{Pathophysiological Mechanism(s) Whereby the Components of the Metabolic Syndrome Promote the Development of Cancer}

In this section we shall discuss potential pathophysiological mechanisms whereby components of the metabolic syndrome may promote the development of cancer. The potential mechanisms may act additively or synergistically to promote cancer associated with the metabolic syndrome (see Figure 1 and Table 2). Mechanistic evidence is summarized at the end of each section as follows: strong: human correlative studies (may be blood or tumor component, receptor concentrations, or clinical trials) plus in vivo (animal studies) and in vitro (cell culture or other ex vivo) studies; intermediate: in vivo (animal studies) plus in vitro (cell culture or other ex vivo) studies.

\section{Insulin Resistance/Hyperinsulinemia}

Insulin resistance may hold the potential to explain many, if not all, of the factors associated with the metabolic syndrome. It can be defined as a condition in which the normal cellular response to insulin is reduced. The pancreatic $\beta$ cells respond by secreting more insulin, leading to increased circulating insulin concentrations (hyperinsulinemia) for insulin to maintain normal plasma glucose concentrations.

Rat tumorigenesis models using various carcinogens followed by insulin injections five times per week confirmed that insulin promotes colon cancer in vivo. ${ }^{33}$ It has been suggested that the promotion of colonic tumors by insulin may be attributable to insulin's ability to promote farnesylation of ras, which allows ras translocation to the plasma membrane for cell signaling ${ }^{33}$; the majority of colonic tumors have ras mutations that 
Table 7. Referenced Multivariate Epidemiology Studies Examining Metabolic Syndrome Risk Factors and Cancer Incidence/Mortality for Endometrial and Prostate Cancer

\begin{tabular}{|c|c|c|c|}
\hline Study & $\begin{array}{l}\text { Furberg and Thune, } \\
2003^{15}\end{array}$ & Xu et al, $2005^{21}$ & Wuermli et al, $2005^{38}$ \\
\hline Cancer type & Endometrial & Endometrial & Prostate \\
\hline $\begin{array}{l}\text { Results (relative risk ratio } \\
\qquad 95 \% \mathrm{Cl} \text { ) }\end{array}$ & $\begin{array}{l}\text { BMI }>30 \text { versus <25: } 2.57 \\
\quad(1.61,4.10)^{\ddagger} ; \\
\text { Hypertensive }(\geq 140 / 90 \\
\text { mm } \mathrm{Hg}) \text { versus } \\
\text { normotensive: } 3.47 \\
(1.24,9.70)^{\star} ; \\
\text { Serum glucose }(\geq 6.1 \\
\text { versus }<5.2 \mathrm{mmol} / \mathrm{L}): \\
1.88(1.07,3.33)^{\star}\end{array}$ & $\begin{array}{l}\text { Waist/hip ratio }(>0.855 \\
\text { versus } \leq 0.782): 2.6 \\
(1.9,3.6)^{+} ; \\
\text {Diabetes and BMI Q4: } \\
4.3(2.5,7.3)^{\dagger} ; \\
\text { Waist circumference } \\
(>86 \text { versus } \leq 73 \mathrm{~cm}) \text { : } \\
3.9(2.5,5.9)^{\dagger} ; \\
\text { Diabetes and waist } \\
\text { circumference Q4: } 6.0 \\
(3.6,10.1)^{\dagger}\end{array}$ & $\begin{array}{l}\text { Serum triglyceride: cancer } \\
\text { mortality } 1.148(1.003 \\
1.315)^{\star}\end{array}$ \\
\hline Size and type & $\begin{array}{l}\text { Norwegian women (all } \\
\text { ages) } n=24,460 \\
\text { population-based cohort } \\
\text { study }\end{array}$ & $\begin{array}{l}\text { Chinese women cases } \\
\begin{array}{l}n=832 \text {, controls } \\
n=846 \text {; population- } \\
\text { based case control study }\end{array}\end{array}$ & $\begin{array}{l}\text { Swiss men cases } n=504, \\
\text { controls } n=565 ; \\
\text { retrospective case } \\
\text { control study }\end{array}$ \\
\hline Covariates & $\begin{array}{l}\text { Age; geographical region; } \\
\text { height; BMI; recreational } \\
\text { and occupational activity; } \\
\text { smoking; parity (BMI not } \\
\text { controlled for } \\
\text { hypertensive cancer risk) }\end{array}$ & $\begin{array}{l}\text { Age; education; years of } \\
\text { menstruation; number of } \\
\text { pregnancies; BMI }\end{array}$ & $\begin{array}{l}\text { Age; BMI; diabetes; } \\
\text { medication with statins }\end{array}$ \\
\hline Inclusion & $\begin{array}{l}\text { Alive with no cancer after } 1 \\
\text { year }\end{array}$ & & $\begin{array}{l}\text { Cases had prostate } \\
\text { carcinoma; controls had } \\
\text { benign prostate } \\
\text { hyperplasia }\end{array}$ \\
\hline Exclusion & & Hysterectomy & \\
\hline Nonsignificant studies & $\begin{array}{l}\text { Energy intake; recreational } \\
\text { activity; occupational } \\
\text { activity }\end{array}$ & $\begin{array}{l}\text { Height; weight; BMI; hip } \\
\text { and waist circumference } \\
\text { and BMI }\end{array}$ & $\begin{array}{l}\text { BMI; age; diabetes; statin } \\
\text { comedication }\end{array}$ \\
\hline
\end{tabular}

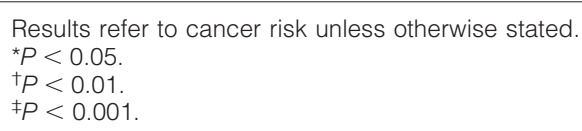

activate this oncogene. Furthermore, the insulin receptor is up-regulated in colon $^{33}$ and breast ${ }^{46}$ tumors, making them more susceptible to the growth stimulatory effects of insulin, particularly during a state of hyperinsulinemia.

Insulin is a major anabolic hormone that can stimulate cell proliferation. The effects of insulin on cancer cell proliferation in vivo may involve an indirect mechanism, such as insulin-like growth factor (IGF)-1 stimulation. Like insulin, IGF-1 plays an important role in cellular proliferation in response to nutrient availability. Growth hormone is the primary stimulus for IGF-1 production in the liver (80\% of circulating IGF-1), and insulin can stimulate IGF-1 production by up-regulating growth hormone receptors in the liver. ${ }^{33}$ Hyperinsulinemia can also increase IGF-1 bioavailability by decreasing hepatic secretion of IGF-binding protein (IGFBP)-1 and -2 so that more IGF-1 is free to bind to its receptor on normal and cancerous cells. The IGF-1 receptor is overexpressed in breast and colon cancers, ${ }^{47}$ and activation of the IGF-1 receptor stimulates the p21 ras/MAPK pathway for cell proliferation and the PI3K/AKT cell survival pathway. ${ }^{48}$ The proliferative and antiapoptotic effects of IGF-1 are important in tumorigenesis because overexpression of IGF-1 stimulates and suppression of IGF-1 reduces mammary tumor development in mutant mice treated with a carcinogen. ${ }^{48}$ Angiogenesis is also stimulated by IGF-1 because it increases vascular endothelial growth factor (VEGF) production in colon, endometrial, breast, and prostate cancer cells (see below). ${ }^{49-51}$ Furthermore epidemiological studies indicate a strong correlation between increased IGF-1 levels, decreased IGFBP-3 levels and coIon, premenopausal breast, and prostate cancer in patients. ${ }^{33}$

Finally, it has been suggested that insulin and free IGF-1 regulate the bioavailability of sex steroids that affect the development of cancers dependent on estrogens and androgens. ${ }^{14}$ Normally, SHBGs produced by the liver circulate bound to estrogens and andro- 
Table 8. Referenced Multivariate Epidemiology Study Examining Metabolic Syndrome Risk Factors and Cancer Incidence/Mortality for Endometrial Cancer

\begin{tabular}{|c|c|}
\hline Study & Xu et al, $2006^{24}$ \\
\hline \multirow[t]{2}{*}{ Results (relative risk ratio $95 \% \mathrm{Cl}$ ) } & $\begin{array}{l}\text { Pre recent BMI Q4 }\left(\geq 25.69 \mathrm{~kg} / \mathrm{m}^{2}\right) \text { versus Q1 }\left(<21.03 \mathrm{~kg} / \mathrm{m}^{2}\right): 3.6(2.2,5.9)^{\star} ; \\
\text { Post recent BMI }\left(\geq 25.69 \mathrm{~kg} / \mathrm{m}^{2}\right) \text { versus Q1 }\left(<21.03 \mathrm{~kg} / \mathrm{m}^{2}\right): 2.7(1.8,4.1)^{\star} ; \\
\text { Pre BMl change/year since age } 20\left(>0.189 \text { versus } \leq 0.049 \mathrm{~kg} / \mathrm{m}^{2}\right): 3.4(2.0,5.8)^{\dagger} ; \\
\text { Post BMl change/year since age } 20\left(>0.189 \text { versus }<0.049 \mathrm{~kg} / \mathrm{m}^{2}\right): 2.7(1.8,4.2)^{\dagger} ; \\
\text { Pre weight change }(\mathrm{kg}) \text { since age } 20 \text { (gain }>20 \mathrm{~kg} \text { versus loss } / \text { gain }<2.5 \mathrm{~kg}): 3.1 \\
(1.8,5.5) ; \\
\left.\text { Peri weight gain with } \mathrm{BMl}<25 \mathrm{~kg} / \mathrm{m}^{2} \text { (gain }>5 \text { versus } \leq 0 \mathrm{~kg}\right): 2.3(1.4,3.9) ; \\
\text { Peri weight gain with } \mathrm{BMl} \geq 25 \mathrm{~kg} / \mathrm{m}^{2}(\text { gain }>5 \text { versus } \leq 0 \mathrm{~kg}): 2.0(1.3,3.0) ; \\
\text { Post weight change }(\mathrm{kg}) \text { since age } 20 \text { (loss }>2.5 \mathrm{~kg} \text { versus loss } / \text { gain }<2.5 \mathrm{~kg}) 0.4 \\
(0.2,1.0)\end{array}$ \\
\hline & $\begin{array}{l}\text { Pre weight change }(\mathrm{kg}) \text { since age } 20 \text { (gain }>20 \mathrm{~kg} \text { verus loss/gain }<2.5 \mathrm{~kg} \text { ); } 2.8 \\
\quad(1.4,5.7)\end{array}$ \\
\hline Size and type & Chinese women cases $n=832$, controls $n=846$; case control study \\
\hline Covariates & $\begin{array}{l}\text { Education; menstrual status; years of menstruation; oral contraceptive use; } \\
\text { number of pregnancies; family history of cancer; adolescent perceived weight } \\
\text { or height at ages 10, 15, and 20; age; BMI at age 20; and initial body weight in } \\
\text { each 10-year adulthood period }\end{array}$ \\
\hline Exclusion & Hysterectomy \\
\hline Nonsignificant studies & $\begin{array}{l}\text { BMl at ages } 20 \text { and } 30 \text { (post), at age } 50 \text { (pre); } \\
\text { Weight gain at age } 20 \text { (post); } \\
\text { Perceived weight at ages 10, 15, and } 20\left(\mathrm{BMl}<25 \mathrm{~kg} / \mathrm{m}^{2}\right)\end{array}$ \\
\hline Other significant studies not listed here & $\begin{array}{l}\text { BMl at ages } 20 \text { and } 30 \text { (pre), at ages 40, 50, and } 60 \text { (pre and post); } \\
\text { Weight gain from ages } 20 \text { to } 30 \text { (pre); at ages } 30 \text { to } 40 \text { (pre and post); from } \\
\text { ages } 40 \text { to } 50 \text {, and } 50 \text { to } 60 \text { (post); } \\
\text { Perceived weight at ages } 10,15 \text {, and } 20 \text { (BMl }<25 \mathrm{~kg} / \mathrm{m}^{2} \text { ); weight change from } \\
\text { age } 20 \text { to recent (all BMls) }\end{array}$ \\
\hline
\end{tabular}

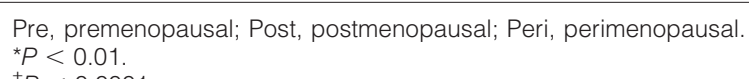

gens to inhibit their receptor binding and cell growth effects. ${ }^{14}$ Hyperinsulinemia and IGF-1 inhibit the synthesis of the SHBGs, thereby promoting sex hormonedependent cancers such as breast, endometrial, and prostate cancers by increasing the bioavailability of sex hormones. ${ }^{14}$ Mechanistic evidence for insulin resistance/hyperinsulinemia is considered strong for coIon and breast cancers based on the growth and IGF1-promoting effects of insulin, as well as the inhibition SHBGs and increased bioavailability of sex hormones.

\section{Obesity (Defined by BMI or WHR)}

\section{Aromatase}

A central feature of the metabolic syndrome is increased WHR or BMI, which reflects an increase in adipose tissue. Estradiol can be formed from the conversion of androgens via the cytochrome P450 enzyme complex known as aromatase, which is present in adipocytes and adipocyte stromal tissue. Circulating concentrations of estradiol in postmenopausal women are directly related to $\mathrm{BMI} .{ }^{52}$ Many breast and endometrial cancers are dependent on estradiol for tumor growth. This could explain observed associations that obesity $\left(\mathrm{BMI}>30 \mathrm{~kg} / \mathrm{m}^{2}\right)$ predisposes to increased estrogen production and is associated with a twofold to fivefold increase in risk of endometrial cancer ${ }^{53}$ and a twofold increase in risk of breast cancer in postmenopausal women. ${ }^{20}$ Furthermore, controlling for circulating estrogen levels in the serum of postmenopausal women significantly reduced the association of BMI with postmenopausal breast cancer risk, ${ }^{52}$ indicating that circulating estrogens are an important pathological mechanism linking obesity with breast cancer development in postmenopausal women. Thus, in postmenopausal women and in men, circulating estrogen concentrations are indicative of androgen conversion to estrogens in adipose tissue and other extragonadal sites.

Although BMI is positively associated with breast cancer in postmenopausal women, wherein the adipose tissue (not the ovaries) are the primary source of estrogen production, ${ }^{54}$ in premenopausal women increased BMI may have a protective effect on the development of premenopausal breast cancer. ${ }^{55}$ Presumably this protective effect is attributable to increased anovulatory menstrual cycles in obese premenopausal women, resulting in a decrease in circulating steroid hormones. ${ }^{56}$ Although abdominal obesity clearly plays a role in increasing circulating estradiol concentrations, there is also evidence in patients that sufficient estrogen could be synthesized by adipocytes in breast tissue to exert proliferative effects on breast cells. ${ }^{54}$

Adipocytes secrete interleukin (IL)-6 and tumor necrosis factor (TNF)- $\alpha$ cytokines, which act together with prostaglandins secreted by fibroblasts as potent inducers of aromatase activity when secreted in a paracrine manner. ${ }^{54}$ Thus, increased adiposity raises cytokine produc- 
tion in obese women that can stimulate aromatase activity and production of estradiol, which is a potent growth factor for estrogen receptor-positive breast and endometrial cancers.

Importantly, aromatase inhibitors are presently recommended for use in postmenopausal women with hormone-dependent breast cancer. ${ }^{57}$ In addition, aromatase activity derived from adipose and endometrial tissues increases circulating levels of estradiol that are directly related to endometrial cancer risk. ${ }^{53}$ Recently, the aromatase inhibitor anastrozole was used to successfully reverse endometrial hyperplasia in obese postmenopausal women. ${ }^{58}$ The aromatase inhibitor letrozole is just beginning to be tested as primary or adjuvant therapy for patients with endometrial cancer; so far the results of the clinical trials look promising. ${ }^{59}$ Evidence for the role of estrogens in breast and endometrial cancer and the importance of aromatization within fat cells to generate estrogens that contribute to cancer cell growth is strong.

\section{Adipokines}

Obesity is, by definition, an increase in fat. Adipocytes, or fat cells, were once thought of as simple storage sites for triglycerides; however, adipocyte synthesis and secretion of hormones, cytokines, and other proteins with signaling properties (collectively termed "adipokines") are evidence that adipose tissue is a complex endocrine organ. Adipokines are a diverse group of signaling molecules that play roles in such processes as appetite and energy balance, inflammation, insulin resistance/sensitivity, angiogenesis, lipid metabolism, cell proliferation, and atherosclerosis. ${ }^{60}$ Many of these functions are related to either the metabolic syndrome or cancer, and they may serve as a link between these two pathologies.

Leptin: Leptin is an adipocyte-specific hormone that serves as a metabolic signal to the brain that results in inhibition of appetite and increased basal metabolism to promote use of the stored energy (fat). Thus, circulating leptin levels are directly related to adiposity. ${ }^{61}$ However, obese patients develop resistance to leptin and consequently become hyperleptinemic and more susceptible to the components of the metabolic syndrome.

In addition to its association with obesity and insulin resistance, increased plasma leptin levels are associated with prostate, colon, breast, and endometrial cancer in patients. ${ }^{62}$ Leptin has consistently been shown to promote cancer cell proliferation in vitro in prostate, colon, breast, and leukemia cancer cell lines. ${ }^{62}$ Leptin stimulates proliferation via MAPK signaling in prostate cancer cells and MCF-7 breast cancer cells; however, in transformed breast epithelial cells it has also been shown to activate STAT3, ERK, and AP-1 pathways leading to cell proliferation. Leptin also contributes to metastasis of cancer cells by stimulating angiogenesis in vitro and in vivo and increasing expression of matrix metalloproteinase-2 and $-9 .{ }^{62}$ Thus, leptin has direct stimulatory effects on cancer cells and may serve as an important link between obesity and cancer development.
Adiponectin: Adiponectin is an adipose-specific 30-kd secreted protein that is the most abundant hormone in circulation, accounting for $0.05 \%$ of serum proteins. Unlike most adipocyte-secreted hormones, adiponectin is significantly reduced in obese patients (BMI $>30 \mathrm{~kg} /$ m2). ${ }^{63}$ Adiponectin has an insulin-sensitizing effect and can ameliorate insulin resistance and diabetes mellitus in two transgenic mouse models overexpressing either fulllength or globular adiponectin. ${ }^{63}$ The primary mechanism for increasing insulin sensitivity is the activation of $5^{\prime}$ AMP-activated protein kinase (AMPK) in the muscle (by globular adiponectin) or in the liver (by full-length adiponectin). ${ }^{63}$ Adiponectin also reduces plasma-free fatty acid concentrations and has anti-inflammatory and antiatherosclerotic properties. ${ }^{63}$ Adiponectin is inversely correlated with breast, endometrial, and gastric cancer risk. ${ }^{64}$ Thus, adiponectin has been inversely correlated with breast, endometrial, and gastric cancer and is known to inhibit inflammation and insulin resistance, both of which are involved in cancer progression.

VEGF (Nascular Endothelial Growth Factor): Angiogenesis is the process of new blood vessel formation from pre-existing vasculature and is a critical process for tumor formation and metastasis. One of the most important proangiogenic factors secreted by adipocytes is VEGF. VEGF and the VEGF receptors (VEGFR-1 and VEGFR-2) modulate endothelial cell proliferation and migration as well as survival, vascular permeability, and tubulogenesis. VEGF is secreted by human fat cells, especially omental fat. ${ }^{65}$ Serum VEGF was positively associated with visceral fat accumulation but not subcutaneous fat, as assessed by computerized tomography scans at the umbilical level. ${ }^{66}$ VEGF secretion by fat and other tissues is stimulated by hypoxia, as well as the following hormones and growth factors: insulin, IGF-1, estrogen, leptin, and TNF- $\alpha$, all of which are increased in obesity and have been discussed above. Although the role of VEGF in angiogenesis and tumor progression is not in doubt, the relative importance of adipocyte-derived VEGF to tumor progression is less clear. One recent study demonstrated an increase in serum VEGF and soluble VEGFR-2 in obese $\left(\geq 25 \mathrm{~m} / \mathrm{kg}^{2}\right)$ versus lean $\left(<25 \mathrm{~m} / \mathrm{kg}^{2}\right)$ patients; however, these data are correlative and cannot identify whether the VEGF was derived from adipose tissue. ${ }^{67}$

Proinflammatory Cytokines: Adipocytes secrete a number of cytokines such as TNF- $\alpha$, IL-6, IL-8, IL-10, macrophage inflammatory protein 1 (MIP-1), and monocyte chemoattractant protein 1 (MCP-1). ${ }^{68}$ It is still unclear why adipocytes produce so many proinflammatory factors in the obese condition, although Trayhurn and Wood ${ }^{60}$ suggest that clusters of adipocytes become hypoxic and secrete cytokines to stimulate angiogenesis into the adipose tissue. TNF- $\alpha$ and IL-6 are consistently increased in the serum and adipose tissue of obese patients. ${ }^{68}$ These cytokines secreted by adipocytes are known to promote insulin resistance and increase circulating triglycerides, features of the metabolic syndrome. ${ }^{69}$

Inflammation has also been linked to many types of cancer, such as gastric, pancreatic, esophageal, liver, bladder, and colorectal cancers because it influences growth, apoptosis, and proliferation of tumor and stromal 
cells. TNF- $\alpha$ activates nuclear factor- $\kappa \mathrm{B}$ (by phosphorylation of its inhibitor $I_{\kappa} \mathrm{B}$ ), which increases production of $\mathrm{NO}$, a substrate for reactive oxygen species (ROS) formation, ${ }^{70}$ and stimulates other inflammatory cytokines. ROS and inflammatory cytokines lead to insulin resistance and glucose intolerance. ${ }^{69,70}$ Thus ROS, inflammatory cytokines, and insulin resistance can promote a vicious cycle, because free fatty acids, glucose, and insulin further stimulate nuclear factor- $\kappa \mathrm{B}$ activation. ${ }^{70}$ Invading white blood cells within the tumor stroma are also an important source of TNF- $\alpha$, IL-6, IL-10, and other cytokines within tumors. Nevertheless, it is likely that increased circulating cytokines from adipocytes promote cancer progression by contributing to inflammation and ROS formation.

There are more than 50 adipokines with diverse functions affecting glucose homeostasis, insulin sensitivity, angiogenesis, adipogenesis, inflammation, cellular proliferation, apoptosis, and differentiation. ${ }^{60}$ Adipokines influence insulin resistance by increasing or decreasing insulin sensitivity. ${ }^{71}$ Because insulin resistance is directly related to the metabolic syndrome and cancer development, adipokines may play a crucial role in linking these two diseases. The evidence for adipokines and proinflammatory cytokines derived from adipose tissue promoting carcinogenesis (either via promoting insulin resistance or directly influencing cancer cells) is considered intermediate.

\section{Impaired Glucose Regulation/Hyperglycemia}

\section{Energy Excess}

The metabolic syndrome is characterized by increased circulating glucose, which cancer cells have specifically adapted to use. Cancer cells have an accelerated metabolic rate and an accompanying high demand for glucose. To accommodate this high demand, cancer cells have an enhanced ability to take up and use glucose. Glucose transporter proteins and especially GLUT1 are increased in many tumors. ${ }^{72}$ GLUT3 has been detected in lung, ovarian, and gastric cancers but not in the corresponding noncancerous tissues. ${ }^{72}$ GLUT12 has been found in prostate and breast cancer, but not in benign prostatic hyperplasia, and was reduced or absent in noncancerous breast tissue. ${ }^{72}$ Furthermore, an accelerated metabolic rate in cancer cells is coupled to an increased requirement for energy and ATP production. ${ }^{73}$ Enzymes involved in glycolysis have been shown to have increased activity and/or expression in cancer cells. ${ }^{72}$ Several studies of patients with different tumor types (including breast cancer) have confirmed that increased glucose uptake/accumulation by tumors correlates with a higher grade of tumor, increased metastatic potential, reduced response to therapy, and poorer survival. ${ }^{72}$

If it is true that excess energy favors cancer development, then energy restriction should hinder cancer development. In fact, energy restriction does inhibit cancer progression. ${ }^{74}$ In animal models energy restriction inhibits several spontaneous neoplasias including tumors that are generated from p53-deficient mice and Wnt-1 transgenic mice. ${ }^{74}$ It also suppresses cancers in rodents in- duced by carcinogens and radiation-induced cancers. ${ }^{74}$ Long-term controlled studies in humans are lacking; however, preliminary data from long-term studies in primates are consistent with an inhibitory effect of energy restriction on cancer progression. ${ }^{75}$ Evidence for an energy excess mechanism is considered strong.

\section{Reactive Oxygen Species}

Excess glucose also promotes the formation of ROS, which can promote cancer development. ROS are highly reactive molecules containing unpaired electrons. With respect to cancer, ROS can damage DNA by several processes including DNA base modification, deletions, frame shifts, strand breaks, DNA-protein cross-links, and chromosomal rearrangements. ${ }^{76}$ DNA damage can occur in genes that are important in cell proliferation (such as ras), or cell survival (such as p53), which can then trigger cancer progression.

Excess glucose drives the polyol/sorbitol pathway in which glucose is converted to sorbitol by aldose reductase. This reaction consumes NADPH, which is required for regenerating reduced glutathione, thereby exacerbating oxidative stress. ${ }^{77}$ The process of nonenzymatic protein glycation is increased by excess glucose and generates advanced glycation end products (AGE) and AGE precursors, which then bind to AGE receptors on macrophages, endothelial, and mesangial cells causing receptor-induced ROS production. In addition, glucose moieties on glycated proteins are capable of donating electrons and forming hydrogen peroxide. ${ }^{77}$ Furthermore, glucose promotes the chemical inactivation of nitric oxide, which has antioxidant capabilities, thereby increasing oxidative stress. ${ }^{78}$

Numerous dietary components, such as olive oil, tea polyphenols, soy, resveratrol, fresh fruit and vegetables, omega-3 fatty acids, selenium, and others with antioxidant activity have demonstrated cancer-protective effects in breast and colon cancer in vitro and in vivo; however, it is not clear whether the antioxidant effect per se is sufficient to account for their anti-cancer effects. Overall, the evidence for an ROS mechanism resulting from increased blood glucose concentrations is considered to be intermediate.

\section{Elevated Triglycerides}

\section{Reactive Oxygen Species}

ROS have been considered as a potential mechanism whereby hyperglycemia causes the development of cancer (see above). However, the generation of ROS by different molecules could potentially work in an additive or synergistic manner to promote cancer development. If this is true, then it is also important to consider mechanistic evidence for hypertriglyceridemia-generated ROS. Mitochondria are the cell powerhouses producing energy in the form of ATP and also ROS. $^{79}$ Increased oxidative stress in fat has been demonstrated to be an important pathogenic mechanism in 
Table 9. The Potential Mechanisms Connecting the Metabolic Syndrome to Cancer Development and Future Areas of Study

\begin{tabular}{|c|c|c|}
\hline $\begin{array}{l}\text { Risk factors for the } \\
\text { metabolic syndrome }\end{array}$ & Potential mechanisms & Future research \\
\hline Obesity & $\begin{array}{l}\text { Aromatase; adipokines; angiogenic } \\
\text { factors; excess energy intake }\end{array}$ & $\begin{array}{l}\text { Identify and characterize adipokines; find } \\
\text { tumor-specific inhibitor of angiogenesis; } \\
\text { inhibit tumorigenic adipose cytokine } \\
\text { production; regulation of energy intake and } \\
\text { expenditure }\end{array}$ \\
\hline Hyperinsulinemia & $\begin{array}{l}\text { Insulin and IGF-1 growth factors; inhibition } \\
\text { of SHBG }\end{array}$ & $\begin{array}{l}\text { Increased insulin sensitivity; reduce } \\
\text { hyperinsulinemia }\end{array}$ \\
\hline Hyperglycemia & Excess energy intake; ROS & $\begin{array}{l}\text { Regulation of energy intake and expenditure; } \\
\text { identify and inhibit ROS }\end{array}$ \\
\hline Hypertension & Unknown & \\
\hline $\begin{array}{l}\text { Dyslipidemia (increased TG, } \\
\text { decreased HDLc) }\end{array}$ & Contributes to IR; ROS & $\begin{array}{l}\text { Increase insulin sensitivity; inhibit ROS, AGEs, } \\
\text { and precursors }\end{array}$ \\
\hline
\end{tabular}

the metabolic syndrome. ${ }^{80}$ Adipocyte NADPH oxidase production of ROS is specifically increased in fat in an obese mouse model, and inhibition of NADPH oxidase improved blood glucose, insulin, and triglyceride concentrations in this model. These data suggest that fat ROS may be a cause of the metabolic syndrome and a possible therapeutic target for obesity-associated metabolic syndrome. ${ }^{80}$ In addition, it has been proposed that excessive cytosolic triglyceride accumulation in nonadipose tissue such as liver and muscle enhances ROS produced by respiring mitochondria by inhibiting adenosine nucleotide translocator and thereby decreasing ADP. The decreased ADP then slows the flow of electrons along the electron transfer chain increasing the likelihood of superoxide anion production. ${ }^{81}$

ROS can also react with lipids; fatty acids are particularly prone to oxidation, forming fatty acid peroxidation products that are highly reactive and that decompose to bifunctional/reactive aldehydes. ${ }^{79}$ The most abundant bifunctional aldehyde is 4-hydroxy-2Enonenal (4-HNE), which has been reported to cause mutation of the p53 gene in human hepatocarcinoma. ${ }^{82}$ In addition, it up-regulates cyclooxygenase-2 (COX-2), which has been linked to breast, colon, and prostate cancers. ${ }^{83}$ Another important reactive aldehyde produced by lipid hydroperoxides is malondialdehyde, which also forms adducts with DNA. ${ }^{79}$ Each triglyceride molecule carries three long-chain fatty acids. Thus, increased triglyceride/fatty acids and obesity contribute to the development of oxidative stress and ROS accompanying the metabolic syndrome. Mechanistic studies linking ROS to cancer are considered to be of intermediate strength.

\section{Summary and Conclusions}

Two large epidemiological studies indicate that clustering of components of the metabolic syndrome increases the risk for the development of colon cancer compared with individual components of the metabolic syndrome (Table 2). One possible explanation for this is that components of the metabolic syndrome promote cancer via different mechanisms that then act in an additive or synergistic manner. Consistent with this notion, we have highlighted several cellular and molecular mechanisms that may link the components of the metabolic syndrome to cancer (Table 9). Specifically, these components may promote cancer development by generating ROS, increasing hormone production/bioavailability (including estrogen, IGF-1, insulin, and adipokines), and providing an energy-rich environment. This imbalance of hormones, the redox system, and energy availability promote cell transformation, angiogenesis, migration, and proliferation, as well as inhibition of apoptosis (Figure 1). These mechanisms have been linked to obesity/BMI, insulin resistance, glucose, and triglycerides/fatty acids; however, the potential molecular mechanisms linking HDLc and hypertension to cancer remain unclear and require further study.

The components of the metabolic syndrome appear to have an additive effect on colon cancer development; nevertheless, it is difficult to distinguish between the primary and secondary mechanisms through which the metabolic syndrome may promote cancer. Although the disease processes associated with obesity and insulin resistance are clearly important, they may act via numerous mechanisms that complement one another in a complex manner (Figure 1). Future basic science research aimed at understanding how adipokines, insulin, and IGFs, and ROS stimulate cancer progression will aid in determining which factors are primary and which are secondary in the development of the metabolic syndrome and how we can potentially intervene in these pathways by use of pharmacological inhibitors, behavioral modification, or gene therapy (Table 9).

Future epidemiology studies are also needed. For example, studies examining the potential link of hypertension and HDLC as independent risk factors for cancer should be designed to control for confounding factors such as BMI, waist circumference, triglyceride concentrations, and insulin resistance. More studies evaluating cancer risk in patients diagnosed with the metabolic syn- 
drome are essential for determining whether individual components of the metabolic syndrome act together to create a greater synergistically/additively increased risk of cancer development compared with individual risk factors. To date, colorectal cancer is the only type of cancer that has been evaluated in patients with $>3$ metabolic syndrome risk factors; the results of these studies show increased risk with multiple metabolic syndrome components in men but not women. The effects of the metabolic syndrome on cancer risk in women should be further evaluated for other types of cancer such as breast or endometrial cancer, taking into account menopausal status.

Understanding the underlying pathological mechanisms and associated risk factors of the metabolic syndrome will provide the information necessary to arrive at a consensus definition of the metabolic syndrome, thereby assisting clinicians in diagnosis and treatment of patients that meet these criteria. If the individual components of the metabolic syndrome are additive in predisposing to cancer, which may be the case for colon cancer, then controlling even just one or two of these components may significantly contribute to living a longer, healthier, cancer-free life. From a clinical standpoint this information would put more emphasis on therapeutic life style changes for metabolic syndrome patients, such as exercise, eating healthy, losing weight, as well as being compliant with prescribed medication(s) to control hypertension, blood glucose, or dyslipidemia.

\section{References}

1. Webster's 9th New Collegiate Dictionary. Edited by FC Mish. Springfield, Merriam-Webster Inc., 1989

2. Beck-Nielsen H, Hother-Nielsen O: Obesity in type 2 diabetes mellitus. Diabetes Mellitus. Edited by D LeRoith, SI Taylor, JM Olefsky. Philadelphia, Lippincott Williams \& Wilkins, 2004, pp 857-868

3. Reaven GM: Banting Lecture 1988. Role of insulin resistance in human disease. Diabetes 1988, 37:1595-1607

4. Moller DE, Kaufman KD: Metabolic syndrome: a clinical and molecular perspective. Annu Rev Med 2005, 56:45-62

5. Kahn R, Buse J, Ferrannini E, Stern M: The metabolic syndrome: time for a critical appraisal: joint statement from the American Diabetes Association and the European Association for the Study of Diabetes. Diabetes Care 2005, 28:2289-2304

6. Grundy SM, Brewer Jr HB, Cleeman JI, Smith Jr SC, Lenfant C: Definition of metabolic syndrome: report of the National Heart, Lung, and Blood Institute/American Heart Association conference on scientific issues related to definition. Circulation 2004, 109:433-438

7. Colangelo LA, Gapstur SM, Gann PH, Dyer AR, Liu K: Colorectal cancer mortality and factors related to the insulin resistance syndrome. Cancer Epidemiol Biomarkers Prev 2002, 11:385-391

8. Trevisan M, Liu J, Muti P, Misciagna G, Menotti A, Fucci F: Markers of insulin resistance and colorectal cancer mortality. Cancer Epidemiol Biomarkers Prev 2001, 10:937-941

9. Morita T, Tabata S, Mineshita M, Mizoue T, Moore MA, Kono S: The metabolic syndrome is associated with increased risk of colorectal adenoma development: the Self-Defense Forces health study. Asian Pac J Cancer Prev 2005, 6:485-489

10. Barrett-Connor E, Grady D, Stefanick ML: The rise and fall of menopausal hormone therapy. Annu Rev Public Health 2005, 26:115-140

11. Slattery ML, Sweeney C, Murtaugh M, Ma KN, Wolff RK, Potter JD, Caan BJ, Samowitz W: Associations between ERalpha, ERbeta, and $\mathrm{AR}$ genotypes and colon and rectal cancer. Cancer Epidemiol Biomarkers Prev 2005, 14:2936-2942
12. Foley EF, Jazaeri AA, Shupnik MA, Jazaeri O, Rice LW: Selective loss of estrogen receptor beta in malignant human colon. Cancer Res 2000, 60:245-248

13. Pasanisi P, Berrino F, De Petris M, Venturelli E, Mastroianni A, Panico S: Metabolic syndrome as a prognostic factor for breast cancer recurrences. Int J Cancer 2006, 119:236-238

14. Calle EE, Kaaks R: Overweight, obesity and cancer: epidemiological evidence and proposed mechanisms. Nat Rev Cancer 2004 4:579-591

15. Furberg AS, Thune I: Metabolic abnormalities (hypertension, hyperglycemia and overweight), lifestyle (high energy intake and physical inactivity) and endometrial cancer risk in a Norwegian cohort. Int $J$ Cancer 2003, 104:669-676

16. Hou L, Ji BT, Blair A, Dai Q, Gao YT, Potter JD, Chow WH: Body mass index and colon cancer risk in Chinese people: menopause as an effect modifier. Eur J Cancer 2006, 42:84-90

17. Lahmann PH, Hoffmann K, Allen N, van Gils CH, Khaw KT, Tehard B, Berrino F, Tjonneland A, Bigaard J, Olsen A, Overvad K, ClavelChapelon F, Nagel G, Boeing H, Trichopoulos D, Economou G, Bellos G, Palli D, Tumino R, Panico S, Sacerdote C, Krogh V, Peeters PH, Bueno-de-Mesquita HB, Lund E, Ardanaz E, Amiano P, Pera G, Quiros JR, Martinez C, Tormo MJ, Wirfalt E, Berglund G, Hallmans G, Key TJ, Reeves G, Bingham S, Norat T, Biessy C, Kaaks R, Riboli E: Body size and breast cancer risk: findings from the European Prospective Investigation into Cancer And Nutrition (EPIC). Int J Cancer 2004, 111:762-771

18. Calle EE, Rodriguez C, Walker-Thurmond K, Thun MJ: Overweight, obesity, and mortality from cancer in a prospectively studied cohort of U.S. adults. N Engl J Med 2003, 348:1625-1638

19. Friedenreich CM: Review of anthropometric factors and breast cancer risk. Eur J Cancer Prev 2001, 10:15-32

20. Morimoto LM, White E, Chen Z, Chlebowski RT, Hays J, Kuller L, Lopez AM, Manson J, Margolis KL, Muti PC, Stefanick ML, McTiernan A: Obesity, body size, and risk of postmenopausal breast cancer: the Women's Health Initiative (United States). Cancer Causes Control 2002, 13:741-751

21. Xu WH, Matthews CE, Xiang YB, Zheng W, Ruan ZX, Cheng JR, Gao YT, Shu XO: Effect of adiposity and fat distribution on endometrial cancer risk in Shanghai women. Am J Epidemiol 2005, 161:939-947

22. Schoen RE, Tangen CM, Kuller LH, Burke GL, Cushman M, Tracy RP, Dobs A, Savage PJ: Increased blood glucose and insulin, body size, and incident colorectal cancer. J Natl Cancer Inst 1999, 91:1147-1154

23. Kaaks R, Van Noord PA, Den T, I, Peeters PH, Riboli E, Grobbee DE: Breast-cancer incidence in relation to height, weight and body-fat distribution in the Dutch "DOM" cohort. Int J Cancer 1998, 76:647-651

24. Xu WH, Xiang YB, Zheng W, Zhang X, Ruan ZX, Cheng JR, Gao YT Shu XO: Weight history and risk of endometrial cancer among Chinese women. Int J Epidemiol 2006, 35:159-166

25. Bird CL, Frankl HD, Lee ER, Haile RW: Obesity, weight gain, large weight changes, and adenomatous polyps of the left colon and rectum. Am J Epidemiol 1998, 147:670-680

26. Nilsen TI, Vatten LJ: Prospective study of colorectal cancer risk and physical activity, diabetes, blood glucose and BMI: exploring the hyperinsulinaemia hypothesis. Br J Cancer 2001, 84:417-422

27. Henriksen EJ: Invited review: effects of acute exercise and exercise training on insulin resistance. J Appl Physiol 2002, 93:788-796

28. Thune I, Furberg AS: Physical activity and cancer risk: dose-response and cancer, all sites and site-specific. Med Sci Sports Exerc 2001, 33:S530-S550

29. Jee SH, Ohrr H, Sull JW, Yun JE, Ji M, Samet JM: Fasting serum glucose level and cancer risk in Korean men and women. JAMA 2005, 293:194-202

30. Nathan DM, Hamman RF, Garfield S, Brenneman A, Fowler SF, Knowler WC: Preventing type 2 diabetes mellitus. Diabetes Mellitus. Edited by D LeRoith, SI Taylor, JM Olefsky. Philadelphia, Lippincott Williams \& Wilkins, 2004, pp 1078-1079

31. La Vecchia C, Negri E, Franceschi S, D'Avanzo B, Boyle P: A casecontrol study of diabetes mellitus and cancer risk. Br J Cancer 1994, 70:950-953

32. Berstein LM, Kvatchevskaya JO, Poroshina TE, Kovalenko IG, Tsyrlina EV, Zimarina TS, Ourmantcheeva AF, Ashrafian L, Thijssen JH: 
Insulin resistance, its consequences for the clinical course of the disease, and possibilities of correction in endometrial cancer. J Cancer Res Clin Oncol 2004, 130:687-693

33. Giovannucci E: Insulin, insulin-like growth factors and colon cancer: a review of the evidence. J Nutr 2001, 131:3109S-3120S

34. Goodwin PJ, Ennis M, Pritchard KI, Trudeau ME, Koo J, Madarnas Y, Hartwick W, Hoffman B, Hood N: Fasting insulin and outcome in early-stage breast cancer: results of a prospective cohort study. J Clin Oncol 2002, 20:42-51

35. Hammarsten J, Hogstedt B: Clinical, haemodynamic, anthropometric, metabolic and insulin profile of men with high-stage and high-grade clinical prostate cancer. Blood Press 2004, 13:47-55

36. Furberg AS, Veierod MB, Wilsgaard T, Bernstein L, Thune I: Serum high-density lipoprotein cholesterol, metabolic profile, and breast cancer risk. J Natl Cancer Inst 2004, 96:1152-1160

37. Michalaki V, Koutroulis G, Syrigos K, Piperi C, Kalofoutis A: Evaluation of serum lipids and high-density lipoprotein subfractions (HDL2, HDL3) in postmenopausal patients with breast cancer. Mol Cell Biochem 2005, 268:19-24

38. Wuermli L, Joerger M, Henz S, Schmid HP, Riesen WF, Thomas G, Krek W, Cerny T, Gillessen S: Hypertriglyceridemia as a possible risk factor for prostate cancer. Prostate Cancer Prostatic Dis 2005, 8:316-320

39. Tsushima M, Nomura AM, Lee J, Stemmermann GN: Prospective study of the association of serum triglyceride and glucose with colorectal cancer. Dig Dis Sci 2005, 50:499-505

40. Ray G, Husain SA: Role of lipids, lipoproteins and vitamins in women with breast cancer. Clin Biochem 2001, 34:71-76

41. Gaard M, Tretli S, Urdal P: Risk of breast cancer in relation to blood lipids: a prospective study of 31,209 Norwegian women. Cancer Causes Control 1994, 5:501-509

42. Tulinius $\mathrm{H}$, Sigfusson N, Sigvaldason H, Bjarnadottir K, Tryggvadottir L: Risk factors for malignant diseases: a cohort study on a population of 22,946 Icelanders. Cancer Epidemiol Biomarkers Prev 1997, 6:863-873

43. Grossman E, Messerli FH, Boyko V, Goldbourt U: Is there an association between hypertension and cancer mortality? Am J Med 2002 112:479-486

44. Sung KC, Ryu SH: Insulin resistance, body mass index, waist circumference are independent risk factor for high blood pressure. Clin Exp Hypertens 2004, 26:547-556

45. Halperin RO, Sesso HD, Ma J, Buring JE, Stampfer MJ, Gaziano JM: Dyslipidemia and the risk of incident hypertension in men. Hypertension 2006, 47:45-50

46. Milazzo G, Giorgino F, Damante G, Sung C, Stampfer MR, Vigneri $\mathrm{R}$, Goldfine ID, Belfiore A: Insulin receptor expression and function in human breast cancer cell lines. Cancer Res 1992, 52:3924-3930

47. Moschos SJ, Mantzoros CS: The role of the IGF system in cancer: from basic to clinical studies and clinical applications. Oncology 2002, 63:317-332

48. Ibrahim YH, Yee D: Insulin-like growth factor-I and cancer risk. Growth Horm IGF Res 2004, 14:261-269

49. Hoeben A, Landuyt B, Highley MS, Wildiers H, Van Oosterom AT, De Bruijn EA: Vascular endothelial growth factor and angiogenesis. Pharmacol Rev 2004, 56:549-580

50. Kucab JE, Dunn SE: Role of IGF-1R in mediating breast cancer invasion and metastasis. Breast Dis 2003, 17:41-47

51. Stearns M, Tran J, Francis MK, Zhang H, Sell C: Activated Ras enhances insulin-like growth factor I induction of vascular endothelial growth factor in prostate epithelial cells. Cancer Res 2005, 65:2085-2088

52. Key TJ, Appleby PN, Reeves GK, Roddam A, Dorgan JF, Longcope C, Stanczyk FZ, Stephenson Jr HE, Falk RT, Miller R, Schatzkin A, Allen DS, Fentiman IS, Key TJ, Wang DY, Dowsett M, Thomas HV, Hankinson SE, Toniolo P, Akhmedkhanov A, Koenig K, Shore RE, Zeleniuch-Jacquotte A, Berrino F, Muti P, Micheli A, Krogh V, Sieri S, Pala V, Venturelli E, Secreto G, Barrett-Connor E, Laughlin GA, Kabuto M, Akiba S, Stevens RG, Neriishi K, Land CE, Cauley JA, Kuller LH, Cummings SR, Helzlsouer KJ, Alberg AJ, Bush TL, Comstock GW, Gordon GB, Miller SR, Longcope C: Body mass index, serum sex hormones, and breast cancer risk in postmenopausal women. J Natl Cancer Inst 2003, 95:1218-1226

53. Kaaks R, Lukanova A, Kurzer MS: Obesity, endogenous hormones, and endometrial cancer risk: a synthetic review. Cancer Epidemiol Biomarkers Prev 2002, 11:1531-1543

54. Reed MJ, Purohit A: Aromatase regulation and breast cancer. Clin Endocrinol (Oxf) 2001, 54:563-571

55. Tehard B, Clavel-Chapelon F: Several anthropometric measurements and breast cancer risk: results of the E3N cohort study. Int J Obes (Lond) 2006, 30:156-163

56. Calle EE, Thun MJ: Obesity and cancer. Oncogene 2004, 23:6365-6378

57. Brueggemeier RW, Hackett JC, Diaz-Cruz ES: Aromatase inhibitors in the treatment of breast cancer. Endocr Rev 2005, 26:331-345

58. Agorastos T, Vaitsi V, Pantazis K, Efstathiadis E, Vavilis D, Bontis JN: Aromatase inhibitor anastrozole for treating endometrial hyperplasia in obese postmenopausal women. Eur J Obstet Gynecol Reprod Biol 2005, 118:239-240

59. Berstein L, Maximov S, Gershfeld E, Meshkova I, Gamajunova V, Tsyrlina E, Larionov A, Kovalevskij A, Vasilyev D: Neoadjuvant therapy of endometrial cancer with the aromatase inhibitor letrozole: endocrine and clinical effects. Eur J Obstet Gynecol Reprod Biol 2002, 105:161-165

60. Trayhurn P, Wood IS: Adipokines: inflammation and the pleiotropic role of white adipose tissue. Br J Nutr 2004, 92:347-355

61. Kershaw EE, Flier JS: Adipose tissue as an endocrine organ. J Clin Endocrinol Metab 2004, 89:2548-2556

62. Somasundar P, McFadden DW, Hileman SM, Vona-Davis L: Leptin is a growth factor in cancer. J Surg Res 2004, 116:337-349

63. Kadowaki T, Yamauchi T: Adiponectin and adiponectin receptors Endocr Rev 2005, 26:439-451

64. Ishikawa M, Kitayama J, Kazama S, Hiramatsu T, Hatano K, Nagawa $\mathrm{H}$ : Plasma adiponectin and gastric cancer. Clin Cancer Res 2005, 11:466-472

65. Hausman GJ, Richardson RL: Adipose tissue angiogenesis. J Anim Sci 2004, 82:925-934

66. Miyazawa-Hoshimoto S, Takahashi K, Bujo H, Hashimoto N, Saito Y: Elevated serum vascular endothelial growth factor is associated with visceral fat accumulation in human obese subjects. Diabetologia 2003, 46:1483-1488

67. Silha JV, Krsek M, Sucharda P, Murphy LJ: Angiogenic factors are elevated in overweight and obese individuals. Int $J$ Obes (Lond) 2005, 29:1308-1314

68. Fantuzzi G: Adipose tissue, adipokines, and inflammation. J Allergy Clin Immunol 2005, 115:911-919

69. Shoelson SE, Lee J, Goldfine AB: Inflammation and insulin resistance. J Clin Invest 2006, 116:1793-1801

70. Sonnenberg GE, Krakower GR, Kissebah AH: A novel pathway to the manifestations of metabolic syndrome. Obes Res 2004, 12:180-186

71. Pittas AG, Joseph NA, Greenberg AS: Adipocytokines and insulin resistance. J Clin Endocrinol Metab 2004, 89:447-452

72. Macheda ML, Rogers S, Best JD: Molecular and cellular regulation of glucose transporter (GLUT) proteins in cancer. J Cell Physiol 2005, 202:654-662

73. Warburg O: On the origin of cancer cells. Science 1956, 123:309-314

74. Hursting SD, Lavigne JA, Berrigan D, Perkins SN, Barrett JC: Calorie restriction, aging, and cancer prevention: mechanisms of action and applicability to humans. Annu Rev Med 2003, 54:131-152

75. Lane MA, Black A, Handy A, Tilmont EM, Ingram DK, Roth GS: Caloric restriction in primates. Ann NY Acad Sci 2001, 928:287-295

76. Valko M, Izakovic M, Mazur M, Rhodes CJ, Telser J: Role of oxygen radicals in DNA damage and cancer incidence. Mol Cell Biochem 2004, 266:37-56

77. Huerta MG, Nadler JL: Oxidative stress, inflammation, and diabetic complications. Diabetes Mellitus. Edited by D LeRoith, SI Taylor, JM Olefsky. Philadelphia, Lippincott Williams \& Wilkins, 2004, pp 14851501

78. Brodsky SV, Morrishow AM, Dharia N, Gross SS, Goligorsky MS: Glucose scavenging of nitric oxide. Am J Physiol 2001, 280:F480-F486

79. Cejas P, Casado E, Belda-Iniesta C, De Castro J, Espinosa E, Redondo A, Sereno M, Garcia-Cabezas MA, Vara JA, DominguezCaceres A, Perona R, Gonzalez-Baron M: Implications of oxidative stress and cell membrane lipid peroxidation in human cancer (Spain). Cancer Causes Control 2004, 15:707-719

80. Furukawa S, Fujita T, Shimabukuro M, Iwaki M, Yamada Y, Nakajima 
Y, Nakayama O, Makishima M, Matsuda M, Shimomura I: Increased oxidative stress in obesity and its impact on metabolic syndrome. J Clin Invest 2004, 114:1752-1761

81. Bakker SJ, ljzerman RG, Teerlink T, Westerhoff HV, Gans RO, Heine RJ: Cytosolic triglycerides and oxidative stress in central obesity: the missing link between excessive atherosclerosis, endothelial dysfunction, and beta-cell failure? Atherosclerosis 2000, 148:17-21
82. Hu W, Feng Z, Eveleigh J, Iyer G, Pan J, Amin S, Chung FL, Tang MS: The major lipid peroxidation product, trans-4-hydroxy-2-nonenal, preferentially forms DNA adducts at codon 249 of human p53 gene, a unique mutational hotspot in hepatocellular carcinoma. Carcinogenesis 2002, 23:1781-1789

83. Brown JR, DuBois RN: COX-2: a molecular target for colorectal cancer prevention. J Clin Oncol 2005, 23:2840-2855 